Article

\title{
Abundant Publications but Minuscule Impact: The Irrelevance of Academic Accounting Research on Practice and the Profession
}

\author{
Kym Fraser 1,2,3,*iD and Benedict Sheehy ${ }^{4}$ \\ 1 Future Industries Institute, University of South Australia, Adelaide 5001, Australia \\ 2 Kurdistan Business School, University of Kurdistan Hewler, Erbil 44001, Iraq \\ 3 Centre for Logistics, Aalborg University, 9000 Aalborg, Denmark \\ 4 Canberra Law School, University of Canberra, Canberra 2601, Australia; benedict.sheehy@canberra.edu.au \\ * Correspondence: kym.fraser@unisa.edu.au
}

Received: 13 June 2020; Accepted: 27 October 2020; Published: 31 October 2020

check for updates

\begin{abstract}
Criticism about the practical usefulness of academic accounting research produced in university business schools has been growing for some time. Due to accounting being an applied social science, many stakeholders question the relevance and value of research published in accounting journals to the accounting profession, practitioners and society in general. This paper highlights the various areas of criticism and discusses factors which underline the issue. While most of the criticism is anecdotal, this study sets about to empirically explore practitioners' perception of academia, and research published in academic accounting journals. To better understand the situation in accounting, a comparison of two other applied academic disciplines is undertaken, involving medical and engineering practitioners. The study found that for accounting there were major differences in the sourcing of information, and significant differences between the other two applied fields with respect to the utilisation and the need for academic material. The findings lead to the conclusion that academic accounting researchers are now nearly totally divorced from the real-world profession of accounting. If we were to take a singular view on the purpose of academic accounting research, then the current situation could leave accounting researchers very vulnerable to adverse decisions with respect to the allocation of future government funding. The conclusions of this paper propose a series of thought-provoking questions about the current state of accounting research, in the hope that it will stimulate debate and generate responses from the accounting community and other stakeholders.
\end{abstract}

Keywords: accounting profession; academic research; research practice gap; real-world relevance; social impact; practical usefulness

\section{Introduction}

There is growing criticism about the usefulness of academic accounting research being undertaken in universities around the world. Concerns stem from the view that accounting is an applied profession and therefore research should benefit the accounting profession, accounting practitioners, and society as a whole. While these concerns are not new, Abdel-Khalik and Keller [1] discussed the impact of accounting research on practice in 1978, the number of dissenting voices is increasing, and criticism is becoming more pronounced. One of the issues regarding such criticism is the anecdotal nature of the concerns coming from the various stakeholders, with empirical studies exploring the depth of the research practice gap in accounting, near non-existent.

Inanga and Schneider [2], on p. 227, state 'there is anecdotal evidence to support the assertion that accounting research, or what is alleged to be research, is of little or no value to the practice of 
accounting, nor to the development of accounting as an academic discipline'. After examining the content within the top-ranked accounting journals from 1963 to 1999, Williams et al. [3] make the following concluding observations. 'After 35 years of extensive financial reporting research, financial reporting is no better and the case could be made that it is worse than it was before all of this research effort started'. They add '...it is not frivolous to question whether accounting has made any progress at all as a scholarly discipline' (p. 813).

The applied nature of social sciences such as accounting makes it essential that theory is grounded in practice [4-9]. On this point, Ghoshal [10] (p. 87) argues that 'In essence, social scientists carry an even greater social and moral responsibility than those who work in the physical sciences because, if they hide ideology in the pretense of science, they can cause much more harm. My contention here is that this is precisely what business school academics have done over the last 30 years'. Markides [11] (p. 763) adds weight to Ghoshal's [10] claim by stating 'the perceived persistence of the gap between research and managerial practice is truly remarkable, if not mysterious!'

In an editorial for a Special Issue on the expectation gap in accounting, Brown [12] (p. 95) made the following compelling statement about the accounting profession.

If the content of most accounting journals is considered, there appears to be few authors in accounting who want to apply their academic research skills to practical problems or possibly few outlets for such work. This is regrettable, not least because we seem currently to be rather overwhelmed with practical problems in accounting. Academic accountants working in universities are acutely aware of the criticism levelled at our discipline by the scholars of more traditional subjects, that some of our work lacks a theoretical basis. In some cases this is undoubtedly true, however, if we concentrate our efforts solely on the theoretical and the abstract, we are highly unlikely to write anything that is going to change the world and the accounting and audit world currently appears to be in desperate need of change.

What is changing is the way in which national governments will fund academic research in the future [13-17]. This change is coming via the implementation of performance-based research funding systems (PRFSs), which seeks to make more effective use of funding by evaluating the relevance (usefulness) of academic research to societal needs. While the authors of this paper endorse the use of public money to support university research, the purpose of this study is to examine the current state of accounting research and determine its usefulness to accounting practitioners and society in general.

At this early stage, it is worth pointing out what this paper will and will not cover. Firstly, business schools have two main roles; knowledge transfer (teaching) and knowledge building (research). With respect to accounting, the first and important role is the education of students in gaining accounting qualifications. The second role involves the undertaking of research to advance the accounting discipline and profession. This paper is solely concerned with the second role, the undertaking of accounting research in accounting/business schools. Secondly, it should be noted that criticism of a disconnect between academic research and practice can be found in most 'applied' research fields, such as medicine, engineering, law, psychology, agriculture, education and public health [18]. The focus of this paper is to review the criticism of accounting research, and empirically compare with two other applied fields; medicine and engineering. The selection of medicine and engineering as comparison fields is discussed at the beginning of the methodology section. Lastly, while some in academia argue that academic theory building and producing practical relevant research are mutually exclusive, this paper focuses on the 'applied' nature of research, a mutually inclusive concept supported by many [19-23].

Therefore, the objective of this paper is to comprehensively review the criticism surrounding academic accounting research and then empirically explore its research impact on practice. In a sense, to answer the important question posed by Markides [11] (p. 763) 'how serious the gap between research and practice really is?'. In other words, is the level of anecdotal criticism (mostly opinion based) supported by scientific evidence? Depending on the outcome of this question, future discussions 
and directions regarding the research practice gap in accounting are likely to be argued from a stronger position of certainly by the various stakeholders concerned.

An important point here for the future of academic accounting research is the fact that the 'voices of concern' are not only coming from within academia, but also externally. The accounting industry and professional bodies are asking serious questions about the relevance of accounting research, and many national governments, facing pressure to improve social research outcomes, are implementing performance-based research funding systems. These issues and other related factors are discussed in the proceeding review of literature. The review is split into two parts-the first part highlights the criticism coming from academia and the various stakeholders in the profession. The second part of review focuses on the various issues impacting the research process, including internal and external factors affecting accounting research.

\section{State of Accounting Research: Voices of Concern}

Before reviewing the literature of the subject under investigation, the prevailing and underpinning philosophies and theories should be explored. The identification of theoretical linking streams helps one to understand the various factors impacting the phenomenon under scrutiny, and the outcome of the study can be used to further enhance the development of prevailing theory. With respect to the research practice gap, three streams of theoretical frameworks can be engaged: critical realism (CR); pragmatism; and normalisation process theory (NPT).

From a philosophical point of view, accounting research has been criticised for having a bias towards a single methodological paradigm referred to as a traditional, mainstream, positivism view [24]. A positivism view is only inappropriate when researching a social science phenomenon like accounting, which involves human interactions and their real-life experiences. To overcome this shortcoming, critical realism (CR) is offered as a viable alternative to determine the reality of a social phenomenon. CR, through the triangulation of cognition processes, utilises elements of both positivism and constructivism, rather than solely relying on one or the other [25]. Due to the applied impact of accounting on individuals, organisations and societies, Baker and Bettner [26] claim that a CR perspective is fundamental to research in accounting. This perspective is more relative to comprehending the role of accounting in shaping the world today, especially as a philosophical paradigm.

To consider the increasing gap between practice and academia, Fendt et al. [27] propose the use of a philosophy such as pragmatism. As a theoretical framework, pragmatism argues that the underlying test of a theory rests mainly on one's desire to prove or disprove it, and the emphasis here is on the link in committing to an action to gather the truth. Pragmatists believe the development of scientific theory and knowledge should be used for bettering human lives or improving organizations and societies, as only then is it considered a useful development [28]. To assist this process, epistemology aids in understanding the idea of practical usefulness-whether the information or knowledge is credible, well-founded, reliable and relevant; and normative-whether knowledge/theory aids in the development of one's cause or betters one's conditions [29]. As long as the scientific inquiry is valid and suitable for the study's reality, pragmatism does not favour a specific paradigm, so long as the selected paradigm offers useful outcomes.

The normalisation process theory (NPT) facilitates the identification of factors that both promote and prevent the everyday practice of regular inclusion of complex interventions. This theory explains how such interventions take place, starting from early implementation and further to an extent where an intervention becomes deeply rooted into regular practice to the point where it 'disappears' from sight (i.e., it is normalised). The focus of NPT is 'how and why things become, or don't become, routine and normal components of everyday work' [30] (p. 535). Four main mechanisms are defined by NPT, which influence the social processes of implementation, embedding and integration of a collection of social practices. The first of these interlinked mechanisms is 'coherence' - the degree to which an intervention is considered meaningful, achievable and desirable; the second is, 'cognitive participation' - the enrolment of those actors essential to the interventions delivery; third, collective 
action —-the efforts used to bring the intervention into practice; and lastly, 'reflexive monitoring' - the on-going process of regulating the intervention to make sure it stays in place.

The deficiencies in the prevailing theories, which are causing a scientific vacuum between academic accounting researchers and accounting practitioners, is the important communication link between academia and practitioners, referred to as the 'transfer of knowledge', and the decline in the normalisation of research into applied practice. This study aims at exploring these issues in-depth, therefore highlighting the level of the scientific vacuum in the accounting profession in the hope that the current research practice gap can be abridged.

The following review of literature was undertaken using the major business databases such as Emerald, EbscoHost (Taylor and Francis), ScienceDirect (Elsevier), SAGE, SpringerLink and Wiley. The searches of each database were conducted using a range of keywords associated with the subject area. While most related material was viewed, the literature highlighted in this review tends to focus on the last 30 years, since 1990. The use of headings such as 'High profile academics' and 'Senior accounting researchers' holds no differentiation, except only to demonstrate the range of dissenting voices.

\subsection{High Profile Academics}

Markides, McCarthy, Humphrey and Gendron [11,22,31] argue that the people calling for an overhaul of accounting research are not in the absence of integrity or credibility. One of many respected academics is Emeritus Professor Richard Laughlin, of King's College at the University of London. In an interview for Campus Review, he states that 'research needs to align with what policy-makers and practitioners need. We're now talking about research in terms of quality outcomes. Is it relevant to practitioners? How does it impact policy-makers? What impact does it make on society?' [32] (p. 1). On another occasion, Professor Laughlin goes further by saying accounting researchers are too often isolated by choice, explaining that 'many accounting researchers often do not bother to even try to engage and instead spend their entire career just talking to other accounting researchers about their work through conferences and journals' [26] (p. 24). He adds, 'It would be unheard of in medicine for practitioners to practice on patients with cures that had not been thoroughly researched, developed and operationalised by policy makers. Equally policy makers would not develop their own policies without due respect for research into evidence-based cures undertaken by academic research' [33] (p. 25).

In a discussion on the current state of the accounting profession, another respected academic, Robert Kaplan, had the following to say, 'as accounting scholars have focused on understanding how markets and users process accounting data, they have distanced themselves from the accounting process itself. Accounting scholarship has failed to address important measurement and valuation issues that have arisen in the past 40 years of practice. This gap is illustrated with missed opportunities in risk measurement and management and the estimation of the fair value of complex financial securities' [34] (p. 367).

Another respected voice and critic of accounting research is Anthony Hopwood [35,36]. He makes the point 'that while business itself was interesting and exciting, many business schools are so boring'. He goes on to argue that 'the research community has invested insufficiently in mechanisms for engaging with the ever-changing world of practice. No longer recruiting so heavily from those with a background in the practice of the art, the world of research has become an increasingly autonomous one with the primary conversations being internal to the community rather than of a more heterogeneous nature. Even within the academic world, accounting scholars seem to relate primarily to themselves' [35] (p. 1370).

Emeritus Professor Robert Scapens agrees that academic accounting researchers should give substantially more deliberation to practical/real-world outcomes when publishing their findings in academic journals. Such deliberations could be for accountants, managers, organisations, policy makers, politicians, governments, professional bodies, and/or anyone with an interest in the social 
impact of accounting. Scapens goes on to say that research scholars need to engage with a wider audience than just their academic colleagues. He argues that the more researchers seek and allow outside interaction, the more the real-world relevance of their work can be demonstrated $[37,38]$.

\subsection{Senior Accounting Researchers}

Kenneth Merchant, a respected management accounting expert, provides an excellent discussion on the current criticism surrounding the usefulness of accounting research [23]. He argues that very little of the management accounting research being produced is useful to practitioner and therefore has no meaningful impact on the accounting profession and practice. Over an academic accounting career spanning more than three decades, he believes that the situation has significantly deteriorated, and proposes the very relevant question: 'Are we using our scarce research resources wisely?' (p. 336).

In a supporting response to Merchant's paper, Lindsay [20] (p. 357) highlights the point that Merchant's paper 'provides yet another plea by a senior respected member of the accounting academic community calling for more attention to be paid to the relevance and usefulness of management accounting (MA) research for solving problems faced by practitioners'. Lindsay also believes that the research practice gap is continuing to widen, and previous calls to address the situation have gone unheeded. In resignation of the current dire position, Lindsay makes the following comment, 'it is difficult to be optimistic that much progress will be made unless concerted and dramatic action is taken within the academy' (p. 358).

With respect to the situation in the US, McCarthy [22] makes the following telling statement, 'Is accounting research stuck in a rut of repetitiveness and irrelevancy? I would answer yes, and I would even predict that both its gap in relevancy and its gap in innovation are going to continue to get worse if the people and the attitudes that govern inquiry in the American academy remain the same' (p. 833). McCarthy [22] is not alone in his criticism of academic accounting research in the US [21,34,36,39-41].

Inanga and Schneider [2] investigate the reasons why accounting research has failed to improve accounting practice. They argue that 'most, if not all, of what purports to be research in accounting is, in fact, a trivial pursuit. We will demonstrate that accounting is not a science and that the mere use of scientific methodologies does not change the basic facts. We also contend that the reported research is nothing more than correlation analysis, rather than the testing of theories and related hypotheses' (p. 228). The authors go on to say that 'accounting research is not significantly linked to accounting practice because the issues and methods of interest to academic researchers are of little or no consequence to practitioners and, moreover, are not focused on fundamental questions' (p. 228).

When analysing the causes behind the 2008 Global Financial Crisis (GFC), Arnold [35] found that the accounting profession was intimately linked to the disaster, and asks the following question. 'In the years preceding the near collapse of the US financial system, why did the looming catastrophe, inherent in highly financialized economy that was fuelled by irresponsible lending practices, financial engineering, bogus bond ratings, opaque financial instruments, and the growth of a systemically dangerous shadow banking system, escape the attention and critique of academic researchers?' (p. 803). Arnold [42] goes on to say 'While accounting practitioners were involved in the securitization schemes that ultimately led to the crisis, accounting scholars were largely unaware of their activities or the troubles brewing in the credit markets and shadow banking system. The premier academic accounting journals did not address the dangers of structured investments, securitization, and off-balance sheet entities until 2008 when the credit crisis was in full swing. The leading journals published more articles on these topics in 2008 alone then in the ten preceding years (1998-2007) combined' (p. 804).

While Arnold [42] questions the research focus of accounting journals, McDonald et al. [43] (p. 29) take a much stronger stand by claiming that 'chasing overseas publication for esoteric research is a waste of resources and funding'. The authors go on to say, 'It is sad to think that academics now work in a system where many of the most influential thinkers of the past 300 years would be considered 
failures because they ignored scholarly journals to focus instead on writing books and to spend their time engaging in the most pressing issues of the day' (p. 29).

van Helden and Northcott [44] lambast the low level of practical relevance and usefulness of research being conducted in the public accounting sector. The authors argue that accounting researchers not only need to better highlight the practical benefits of their theoretical developments in academic journals, but just as important, is the need to disseminate the practical findings in professional magazines/journals, which many practitioners are provided. The authors end their discussion by concluding 'We therefore call for urgent reflection on the role of leading journals in shaping and reinforcing accepted notions of the value of practical relevance in accounting research' (p. 232).

\subsection{Editors, Journals and Publishers}

When searching for criticism about the social and practical impact of academic accounting research, accounting journal editors and their publishers are unlikely to be a productive source. Having said that, it was of interest to discover a few voices willing to express their concerns. After receiving a poor response to a call for papers on the topic, 'The relationship between theory and practice in management accounting' for the journal, Management Accounting Research, the guest editors expressed their disappointment and concluded by stating 'This probably reflects the academic community's view that the issue of how research and the development of management accounting theory relates to practice is not particularly important' [19] (p. 79).

In 2010, the Publishing Director of the Emerald Group, a large publisher of academic journals in the field of business, made the following passionate plead to readers and academia.

Hardly a day goes by when an article or viewpoint is not brought to our attention that highlights the need to review how research can be more effectively connected to real-world activity and policy setting. This debate has not emerged as a result of the current economic crisis, but it has certainly been brought into sharper focus by it. We are challenged to consider the role of research in contributing to the failures in our financial systems and leadership or, at the very least, in its inability to direct business, economies and societies away from it. So the question remains do we batten down the hatches and hope this particular squall passes over head so that we can return to the processes and systems that we know, or should we use this as an opportunity to find a better solution to an age-old and, unfortunately, increasing problem of disconnection between the world of research and scholarship and the world of practice and policy formation? [45] (p. 118)

To obtain an understanding of the research being published in the world's leading accounting journals prior to the 2008 GFC, the Association of Chartered Certified Accountants (ACCA), the global body for professional accountants, sponsored a report into the content relevance of academic accounting research. The study was conducted by two accounting professors, Jeffrey Unerman and Brendan O'Dwyer [46], and undertook content analysis of the six leading accounting journals for the 10 years prior to the sub-prime disaster, and consequently the GFC. With the earlier collapses of Enron, WorldCom, Arthur Andersen and others highlighting the need for academics to take a more critical examination of accounting practices, the report's findings are a disappointing outcome.

Unerman and O'Dwyer [46] found that most articles published in these six top-tier journals focused on the economic character of accounting, and in several journals, this focus is even further reduced to a specific economic function. Therefore, articles tended to follow the well-researched paradigm that has been dominant in accounting research for the past 30-40 years. The problem with such a morbid mindset is that researchers are not encouraged or challenged to critically analyse the practice of accounting. This is clearly evident in the lack of articles exploring the various new economic and financial instruments being employed by the accounting profession, which were so infamously linked to the near collapse of the financial and economic global systems in 2008. 
The key recommendation from the Unerman and O'Dwyer [46] study is the overarching need to improve the health of accounting research in academia. The authors argue that the research coverage of these leading journals needs to be broadened, which will require a much wider agenda of issues to be critically researched. They believe that it is no longer beneficial to academia; the profession and society to continue to blindly produce endless amounts of research on the assumptions of the dominant paradigm, especially after such a spectacular failure. Adding to the lack of broadness in research topics is the fact that very few of the published articles were researched outside of the United States. This is a problematic situation, because as was shown in the GFC crisis, problems in accounting are a world-wide phenomenon. The authors also stress the point that the editors of these journals need to play a pivotal role in improving the research standards of a profession which is being severely questioned. Unerman and O'Dwyer conclude with the warning that if the leading journals continue with their current narrow research focus, then these journals run the risk of becoming irrelevant, not only to researchers and practice, but also to those who fund accounting research, such as governments and society [46].

\subsection{Business, Governments and Professional Accounting Bodies}

While the criticism within academic ranks has been growing, external pressure is also mounting [47]. David Willetts, the UK's minister for higher education until 2014, is highly critical of business schools for chasing status and rankings via journal publications at the detriment of applied research [48]. Further, Dan LeClair, senior vice-president at the Association to Advance Collegiate Schools of Business (AACSB), which provides accreditation to over 500 universities globally, states 'The deans have been telling us that major donors are asking tough questions like "you have all these faculty members who you are very proud of, but can you tell me how this research has made a difference?"' [48] (p. 31).

The Executive Director of the Australian Technology Network, Vicki Thomson, questioned the benefits to society of Australia universities with 'elitist' attitudes towards certain types of research. She argues that such universities consider pure research as 'elite' research, while at the same time, 'applied' research is considered inferior. Thomson went on to say 'Research, no matter how excellent, that comes without impact for our society is research that is wanting. Too much quality research is based solely on achieving peer review and academic accolades' [49] (p. 31).

In late 2003, the Lambert Report, commissioned by the UK government to review the level of business-university collaboration in the UK, was released. The report was 'critical of a culture in which UK based university researchers largely continue to work in isolation from the world that funds them' [50] (p. 3). Another Government report on the state of the social sciences in the UK found '...the caution of some academics towards close engagement with practitioners is a source of great disappointment to many users of social science research' [51] (p. 27). Brian Singleton-Green, from the Institute of Chartered Accountants in England and Wales (ICAEW), is another who has questioned the ongoing gap between accounting research and its impact on public policy [52,53].

In the OECD's Science, Technology and Industry Scoreboard report released in 2013, Australia ranked last out of 33 countries when comparing the levels of collaboration between business and public research institutions [54]. In response to the OECD report, the CEO of the peak business body representing Australia's businesses stated, 'the real game changer for innovation within Australian businesses will occur once we begin to adequately leverage the research capacity of our highly regarded universities to achieve better commercial outcomes for industry' [55] (p. 4). Due in part to the enormous costs associated with funding research, and coupled with pressure to improve collaboration with business, Australia, like a number of other countries, has started exploring a performance-based research funding system for its higher education sector. Such systems are designed to refocus attention on the relevance of research to practice and society. 


\subsection{Accounting Regulatory Institutions}

In the final section on the discussion of the 'State of accounting research', the following two paragraphs present a damning indictment of the level of disconnect between academic accounting researchers and the profession.

In 1994, the Chairman of the Financial Accounting Standards Board (FASB), Dennis Beresford, pleaded for more ex ante research from academic researchers to support financial accounting standard-setting decisions. Beresford explained that the FASB relied on research in virtually every stage of the standard-setting process, but he felt it was important to communicate the FASB's general concern about the lack of relevant academic research. Beresford listed a number of research areas which needed academic involvement and even made offers of access to data and funding to facilitate the process [56]. Adding weight to Beresford's plead, Leisenring and Johnson [57] also claimed it was important for accounting research academics to guide the standard setting process.

Sadly, 15 years after Beresford's plead, Fulbier et al. [58] made another appeal to the academic accounting community. In a study exploring the influence of accounting scholars and accounting research on policy development at the International Accounting Standards Board (IASB) and the International Financial Reporting Standards (IFRS), it was found that the academic input and impact on these important bodies were very questionable and lacking. The study indicates that the IASB and IFRS are struggling, and have been for over a decade, with a number of unresolved issues, while continuing to debate a significant number of crucial and contentious present topics. The reality is, as argued by the authors, is that the research and support from academia regarding these issues has fallen well short of the standard setters' needs. In the conclusions, the authors make another appeal to academia by stating 'as the FASB has done in the past, the IASB is calling for support from academic accountants' [58] (p. 483).

Having reviewed the state of accounting research, it could be argued that a normalisation process for the profession was underway up to the end of the 1960s. Using normalisation process theory (NPT) as a guide, anecdotal evidence indicates there were efforts to normalise theoretical developments into normal collective practice. From the 1970s, there are strong indications that the focus to normalise or embed academic accounting advancements into routine practice was no longer a priority to accounting researchers. While the previous section highlighted individual voices expressing concern and criticism of the decline in the normalisation process, the following section reviews some of the factors impacted by the decline.

\section{Factors Affecting Accounting Research}

\subsection{Research Practice Gap}

The term research practice gap occurs when a profession and/or practitioners struggle to integrate research and knowledge developed in an academic/research environment with the real-world of practice. In the medical profession, it is common for research to be undertaken in labs, clinics and hospitals and then transferred to the wider society via medical practitioners. In the case of accounting, many in the profession now argue that much of the research produced in universities has little or no impact on practice, therefore creating a gap between research and practice. In 1991, a group of prominent scholars in the US wrote to the Research Director of the American Accounting Association, arguing 'it is difficult to recall one accounting research innovation in the last 20 or so years ... that meaningfully affected accounting standard-setting and securities regulation' [59] (p. 1). Over the next two and half decades since 1991, many have argued that the research practice gap in accounting and business schools has widened [7,22,35,60-64].

After many decades of academic debate on the issue, McNatt et al. [65] recommend two options to overcome the problem. Firstly, they suggest to just accept there is a gap and pay little attention to it, therefore just ignore the gap exists. The second option proposed involves the formation of a new paradigm which would combine the existing two paradigms-'a pracademic or applied academic 
paradigm' (p. 15). Proposing another academic paradigm is interesting, considering a number of scholars argue that paradigm wars between academic accounting elites have already caused the accounting profession great harm [24,66-68]. In a discussion about the ongoing conflict between paradigms (a methodological debate) within the 'elite' academic accounting community, Arnold [42] (p. 804) makes the following statement, 'The need for financial accounting research to reduce its dependence on quantitative databases and develop the methodological tools, institutional knowledge, and links to practice needed to bridge the gap between academic research and the world of 'accounting in action' is one of the most significant challenges posed by the current crisis to accounting research'.

Many make the point that research being produced by business schools, while maintaining methodological standards, should benefit practitioners and/or society in general $[4,23,61,63,69-72]$. Having evolved from the social sciences, the very nature of business schools and the research undertaken is explicitly linked to the applied strand of research. Pettigrew [73] (p. S61) highlights this point by stating 'the duty of the intellectual in society is to make a difference'. Mohrman and Lawler [74] (p. 10) add further support by stating, 'Society has expectations that professional schools will deliver knowledge that can be used in practice'.

Another issue impacting the gap between research and practice is the focus on 'finding a gap in the literature'. Brooks et al. [13] argue that most research in business schools originates from a 'gap-spotting mentality', where research becomes aimed at an increasingly narrow and purely academic audience. Many $\mathrm{PhD}$ candidates experienced first-hand the issue of the 'gap-spotting mentality' [75]. When starting my PhD, an industry-based scholarship, my highly experienced supervisor stressed to me the need for my PhD to be based on a 'gap' in the literature. Having spent 25 years in practice, I struggled with this concept, knowing that the real-world offered endless issues and problems (gaps) to be solved. While I believe that literature is a very important aspect of research and the PhD process, I am somewhat surprised that the 'gaps' for applied PhDs are not generated by practice/society, and the researcher then uses the academic literature to better understand and explain and/or expand the theory and underpinning principles behind the practical problem/s being addressed.

\subsection{Usefulness of Accounting Research}

Since the beginning of the new millennium, the usefulness of academic accounting research has been questioned by many. The greater scrutiny on accounting practices has occurred due to the dramatic collapse of corporations such as HIH Insurance, One.Tel, WorldCom, Swissair and Enron $[3,76,77]$ accumulating into the global disaster known as the Global Financial Crisis (GFC) in 2008. The financial practices of large corporations such as Bear Stearns, Lehman Brothers, AIG and RBS invited further condemnation [42,78]. Hopwood [29] (p. 798) argues that the GFC 'illustrates the dangers of the drift away from the world of accounting practice that has been a characteristic of so much accounting research for the last few decades'.

This 'drift away' from practice has many questioning the usefulness of accounting research being published in the leading accounting journals, with a significant number of these top ranked journals being based in the US $[3,24,36,44,46,66-68,76,79]$. Contributing to the declining usefulness of accounting research has been the emergence of 'closed-loop' systems within the accounting research community, predominantly in the US. These so-called elite groups take predetermined views on how accounting knowledge and understanding is obtained, and those with views that may differ are excluded from the conversation [24]. Several accounting research academics have been critical of the 'closed-loop' development and its effect on producing useful accounting research $[23,64,66,67,80]$. Lee [80] argues that many 'closed-loop' researchers don't read journals outside of their closed publishing loop and dismiss any criticism as peripheral nuisance. Jones et al. [81] (p. 601) state that the US accounting system is 'sort of 'closed shop' which it is very difficult for non-US academics to break into'. With various accounting elites developing their own closed loop systems, the accounting research discussion is then driven into a debate about completing paradigms [24]. The focus on such debates leads to increasingly more questions about how useful the research being published in accounting journals is. 
Having highlighted a deteriorating gap between academic research and the accounting profession, it would be improper to argue that there have not been valuable research contributions to the field. As Lindsay [20] (p. 368) points out, 'when useful research is done well, the payoffs can be extremely high'. The name Robert Kaplan is esteemed in business circles for his work with Robin Cooper on activity-based costing, and later with David Norton on the balanced scorecard [82,83]. Then, there is the work of Hope and Fraser [84], who examined the impact of budgeting on firms' annual performance, and Simons [85] innovative control systems to help drive strategic change. With respect to IFRS, financial accounting research literature is closely aligned to the development of IFRS 15 'Revenue from contracts with customers' [86].

Other influential works include Anthony Hopwood's research on accounting systems and management behavior [87], Kenneth Merchant's work on motivating profit center managers [88], and Trombetta et al. [89] investigate the links between academic research and the accounting standards. These important works have been highlighted by others in the accounting arena $[19,20]$.

As pointed out by Lindsay, a common theme in each of the influential research outputs highlighted above has been the integrative and collaborative nature of the research between academia and practice, with the accounting profession being a stakeholder in the research [20]. While the above success stories are a reminder of what can be achieved, there remains the sad realization in the words of Baldvinsdottir et al. [19] (p. 80) who state: 'it is apparent that the wider accounting research community has little interest in influencing practice or in capturing the practitioner as an audience for their output'.

\subsection{Practical Relevance Versus Academic Rigor}

Much has already been written about the debate between relevance and rigor [90-94]. To make their accounting research more scientific, many scholars have focused on making their research more rigorous, by using more scientific methodologies. Critics believe that this desire to increase the 'academic credibility' of accounting research has coincided with a disregard to make the research relevant and useful for practice. The focus for contemporary accounting scholars, and supported by the top-ranked journals, is to align themselves and their methodologies with economic and finance paradigms rather than in terms of real accounting problems $[2,46,76]$.

According to Diamond [76], the debate surrounding the relevance and usefulness of business and accounting research can be linked to the current discussions concerning universities in general. He argues that prestigious research universities in the US were born from the Cartesian view of the world, which valued the abstract and physical nature over the applied and the contextual. This bias has ultimately led many to question the research relevance of universities, as global societies face insurmountable problems coupled with financial constraints [76].

\subsection{Universities Incentive Structure}

Over the past decade or so, there has been a push by universities, certainly those outside the 'top' elite group, to improve their world university ranking. While national governments have had some input, the major push is coming from within universities themselves, through Vice Chancellors, Faculty Deans, Heads of Schools to academic staff. Universities understand that the international and domestic student market is very competitive, and it is believed that students prefer to study at universities which are highly ranked $[16,95]$. Therefore, universities are putting a greater focus on the factors that can improve their ranking, with recruitment and incentives being geared towards improving the publication performance of universities.

Another linked factor is universities and academic thinking with regards to recruitment and promotion is being incentivized towards publishing in the world's elite journals. Many believe that this focus towards rankings and elitism is having a very detrimental impact on the applied science with the decoupling of academic research from real-world practice. McKinnon [96] (p. 16) states 'It is my contention that the journal ranking system is encouraging a retreat into ivory towers where business academics impress each other with their erudition and give too little thought to the managerial and 
public policy relevance of their work'. Merchant [23] argues the tenure and promotion guidelines of many universities, coupled with the publishing requirements of the top-ranked academic journals, not only restrict, but precludes scholars from undertaking research in certain significant accounting areas.

It is therefore likely that the recent push to publish in 'top' journals will only further increase the growing gap between accounting researchers and the accounting profession. This is unfortunate considering it was not that long ago that the structures of business schools were being designed to foster and enhance the relationship between universities and the accounting profession. During the 1970s and 1980s, many universities in the US considered it beneficial to establish stand-alone accounting schools from the other disciplines nested within business schools. It was argued that the 'professional' relationship between accounting programs and professional/national bodies was similar to other applied professional disciplines such as medicine, education, engineering, law etc. Due to the close working relationship between the academic accounting program and the accounting profession (represented by the Big 8 at that time), it was thought that the accounting discipline would benefit from being semi-autonomous from business schools [76].

\subsection{Public Funding for Research}

Research is highly dependent upon the funding provided by national governments $[7,13,97]$. In 2013, the Australian government allocated around USD 9 billion of taxpayers' money for academic research [98], while in 2011, the U.S. federal government distributed more than $\$ 40$ billion for research to universities across the country [99]. In Europe, universities are primarily funded by public money [100]. Therefore, public business schools are extremely reliant on government money to complement their tuition revenue to fund their teaching and research activities. The very real problem facing research universities, is the fact that the costs of research continues to rise, while at the same time, increasing financial and budgetary pressures is causing governments to reduce direct funding to public research institutions $[17,101]$.

While there is some criticism about using taxpayers' money to fund academic research [102], there exists a general consensus that scientific research can positively impact the advancement of mankind and our changing planet [103]. Pavitt [104] showed that positive social outcomes, such as economic, business, employment and technological opportunities, could be achieved in the US when public money was used to support quality academic research. In 1997, Narin et al. [105] studied the link between patents in American industry and patent applications supported by the published data. The research concluded that $73 \%$ of the research papers cited had been generated in public institutions, with the authors coming from academia or government bodies. The study highlighted the significance of public funded research to the U.S. patents industry. For the period 1988 to 1994 , new patents increased by $30 \%$, while at the same time, the papers being cited from public institutions in these patents grew three-fold [105].

Linked to the issue being highlighted in this paper is the ever-expanding cost of funding public research while national governments are seeking to reduce financial support due to budgetary pressures. It is necessary to emphasize that the purpose of this paper is not to argue against the benefits of public money funding research, but under the prevailing circumstances, there needs to be a 'value for money' test for public funds being provided for applied research in the higher education sector. This accountability of expenditure would put a greater focus on the social impact of research, including an emphasis on closing the current research practice gap, as some have argued $[14,98,106]$.

\subsection{Changing Social/Political Environment}

Presently, there exists reformation policies on science and technology in many OECD countries, with a focus on areas such as applications for government funded grants for research and emerging methods of research evaluation. The underlying rationale behind these considerable developments has been growing pressure on public authorities to become accountable and transparent with public spending. This growing pressure is meant to ensure the higher education sector 
continuously evaluates the efficiency of scarce resources, as well as justifying the need and support for funding $[13,14,17,97,107]$. Due to growing pressure, governments have commenced designing and implementing performance-based research funding systems (PRFSs).

PRFSs are a mechanism through which governments can attempt to increase the effectiveness of the evaluation and distribution of public funding to universities. PRFSs allow limited financial resources to be allocated in a more feasible approach while aligning research efforts to societal needs, especially as countries seek to strengthen the impact of research. PRFS frameworks re-align the focus towards practical/social outcomes in incremental stages. In some cases, research funding is granted based on a set of pre-agreed outcomes. If researchers do not meet desired outcomes, it may impact on opportunities to obtain future research funding. The first country to develop PRFSs was the UK, followed by Australia, and within the last decade, a total of 14 different countries are now in the process of implementing national performance-based systems for their higher education sectors [15]. Linked with the introduction of PRFSs, the UK is altering the method of evaluation used for research publications, away from a focus on the ranking of the journal, to a measure of practical impact value to society, including public policy and practitioners [32]. In Australia, this policy direction has now become national themes for the Australian Technology Network (ATN) and the government.

Using the UK model, the ATN has pressed the Australian Government to use measurable outcomes to determine the benefits and impact of university research on real-world practice and society. The argument made by the ATN is that there must be a shift away from measuring university research performance based exclusively on journal publications, journal quality and researcher citations [108]. The direction of this new policy and measures is a shift towards how relevant or instrumental society values academic research. A report on the research performance of the higher education sector in Europe has advocated the needs for such a policy shift on measuring the research performance of universities [109]. As support for PRFSs grow, it is becoming clear that the model for funding research in many countries is changing to one which will put much greater emphasis on the practical and social outcomes of publicly funded research.

\subsection{Summary of Reviewed Literature}

An overview of the literature reviewed in this study is presented in Table 1. The table lists 68 articles, highlighting the problematic nature of the disconnect between academic research and the practical world. Many of these articles are critical of the practical usefulness and social impact accounting research is having on practitioners and the profession. From the list, 51 directly refer to accounting research, while the remaining 17 examine the broader role of business schools and universities. Clearly, authors with affiliation to either the US or the UK are highly represented, with 23 $(34 \%)$ articles respectively. One of the arguments presented early in this paper is that the number of dissenting voices is increasing, and basic analysis of the content of Table 1 would tend to support this untested hypothesis. For the period 1990-1999, there are 6 articles discussing the research practice gap. This number grows to 25 for the 2000-2009 period, and increases again for the 2010-2019 period to 36 . Since 2005, there have been 58 articles written about the research practice gap, while the remaining 10 were published in the pre-2005 period, therefore adding support to the hypothesis that the voices of concern are growing. 
Table 1. Summary of accounting articles highlighting the research practice gap.

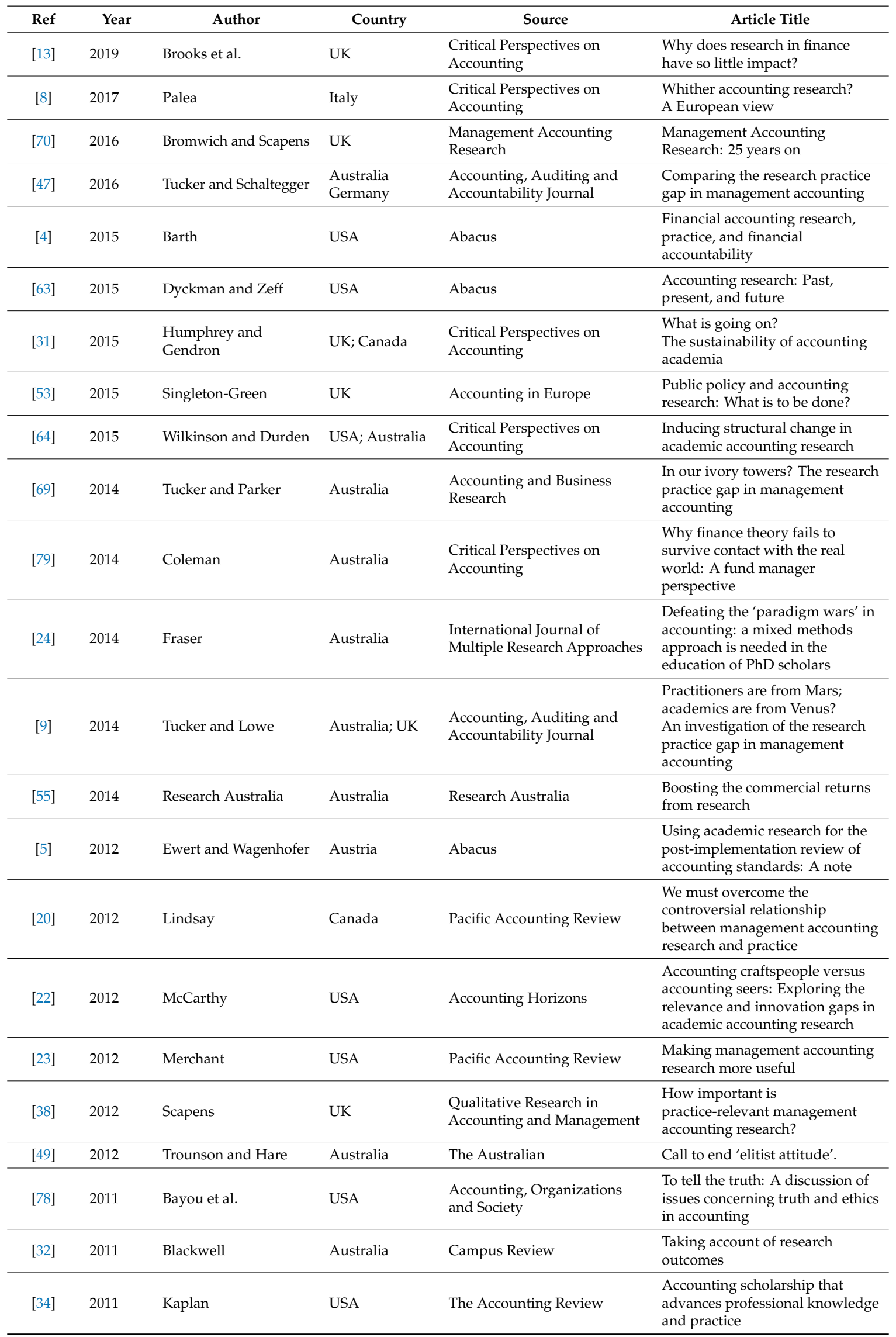


Table 1. Cont.

\begin{tabular}{|c|c|c|c|c|c|}
\hline Ref & Year & Author & Country & Source & Article Title \\
\hline [33] & 2011 & Laughlin & UK & $\begin{array}{l}\text { Bridging the Gap between } \\
\text { Academic Accounting } \\
\text { Research and Professional } \\
\text { Practice }\end{array}$ & $\begin{array}{l}\text { Accounting research, policy and } \\
\text { practice: Worlds together or } \\
\text { worlds apart? }\end{array}$ \\
\hline$[43]$ & 2011 & McDonald et al. & Australia & The Australian & $\begin{array}{l}\text { Let academics work in the real } \\
\text { world }\end{array}$ \\
\hline [72] & 2011 & Rutherford & UK & Accounting in Europe & $\begin{array}{l}\text { Accounting research and } \\
\text { accounting policy: What kind of } \\
\text { gap? }\end{array}$ \\
\hline [48] & 2011 & Schiller & UK & Financial Times & Academia strives for relevance \\
\hline$[67]$ & 2010 & Malmi & Finland & $\begin{array}{l}\text { Management Accounting } \\
\text { Research }\end{array}$ & $\begin{array}{l}\text { Reflections on paradigms in } \\
\text { action in accounting research }\end{array}$ \\
\hline [45] & 2010 & Marsh & UK & $\begin{array}{l}\text { Journal of Applied } \\
\text { Accounting Research }\end{array}$ & Measuring the impact of research \\
\hline [68] & 2010 & Merchant & USA & $\begin{array}{l}\text { Management Accounting } \\
\text { Research }\end{array}$ & $\begin{array}{l}\text { Paradigms in accounting research: } \\
\text { A view from North America. }\end{array}$ \\
\hline [53] & 2010 & Singleton-Green & UK & Accounting in Europe & $\begin{array}{l}\text { The communication gap: Why } \\
\text { doesn't accounting research make } \\
\text { a greater contribution to debates } \\
\text { on accounting policy }\end{array}$ \\
\hline$[40]$ & 2009 & Jeanjean and Ramirez & France & Accounting in Europe & $\begin{array}{l}\text { Back to the origins of positive } \\
\text { theories: A contribution to an } \\
\text { analysis of paradigm changes in } \\
\text { accounting research }\end{array}$ \\
\hline [42] & 2009 & Arnold & USA & $\begin{array}{l}\text { Accounting, Organizations } \\
\text { and Society }\end{array}$ & $\begin{array}{l}\text { Global financial crisis: The } \\
\text { challenge to accounting research }\end{array}$ \\
\hline [12] & 2009 & Brown & UK & $\begin{array}{l}\text { Journal of Applied } \\
\text { Accounting Research }\end{array}$ & $\begin{array}{l}\text { Revisiting the expectations gaps } \\
\text { after } 15 \text { years }\end{array}$ \\
\hline [58] & 2009 & Fulbier et al. & Germany & Abacus & $\begin{array}{l}\text { Relevance of academic research } \\
\text { and researchers' role in the IASB's } \\
\text { financial reporting standard } \\
\text { setting }\end{array}$ \\
\hline [36] & 2009 & Hopwood & UK & $\begin{array}{l}\text { Accounting, Organizations } \\
\text { and Society }\end{array}$ & $\begin{array}{l}\text { The economic crisis and } \\
\text { accounting: Implications for the } \\
\text { research community }\end{array}$ \\
\hline$[7]$ & 2009 & Malmi and Granlund & Finland & European Accounting Review & $\begin{array}{l}\text { In search of management } \\
\text { accounting theory }\end{array}$ \\
\hline$[60]$ & 2008 & Aguinis and Cascio & USA & $\begin{array}{l}\text { The Industrial-Organizational } \\
\text { Psychologist }\end{array}$ & $\begin{array}{l}\text { Narrowing the science-practice } \\
\text { divide: A call to action }\end{array}$ \\
\hline$[62]$ & 2008 & Dess and Markoczy & USA & $\begin{array}{l}\text { Journal of Supply Chain } \\
\text { Management }\end{array}$ & $\begin{array}{l}\text { Rather than searching for the } \\
\text { silver bullet, use rubber bullets: } \\
\text { A view on the research-practice } \\
\text { gap }\end{array}$ \\
\hline
\end{tabular}


Table 1. Cont.

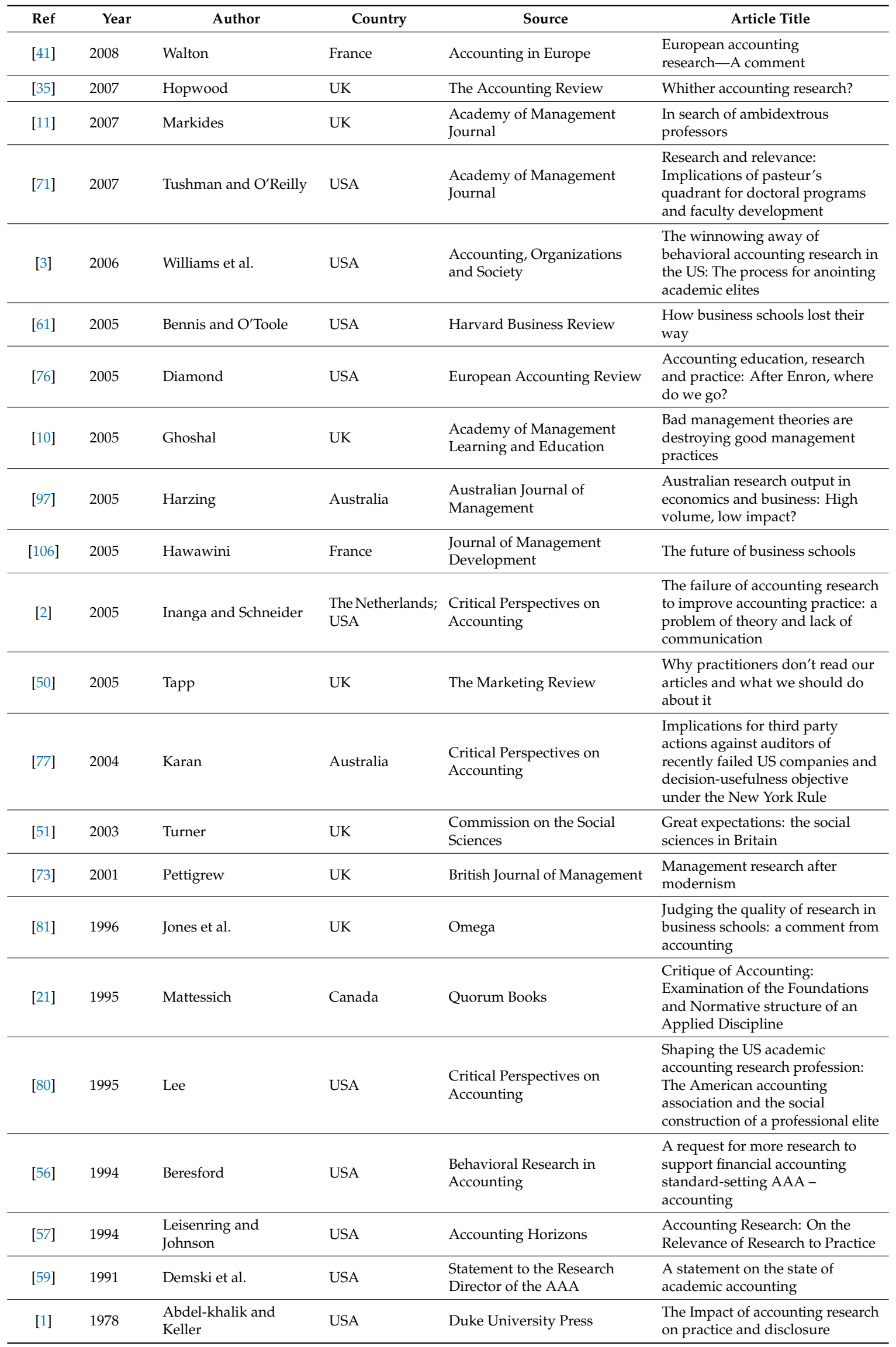




\section{Methodology}

While the preceding review provided anecdotal (mostly opinion-based) criticism of the research practice gap in accounting, the question that this paper is seeking to answer is whether such a critical opinion can be supported by scientific evidence. To answer this question would not only enhance future discussion/debate on the issue, but is also likely to assist key stakeholders in the process (universities, governments, and the profession) regarding decisions about support, opportunities and funding.

Before framing research questions/hypotheses to test the issue, we need to consider a couple of points. Firstly, over the last two decades, criticism of a growing disconnect between accounting researchers and the accounting profession has significantly increased. While the anecdotal accounts have been burgeoning, the scientific support via empirical evidence is very much lacking. Complicating the issue is the fact that many disciplines taught within business schools (management, marketing, economic, organizational behavior, HRM, finance, operations, logistics and supply chain etc.) do not require individuals to obtain a license to practice in the profession, as is required by medicine, education, engineering and law. In other words, most graduates from business schools are not required to: pass profession specialized examinations to obtain a licensed to practice; be a member of an overarching professional national body; pursue continuing education, including scientific knowledge, in order to work in their chosen field. The one exception to the above-mentioned requirements is accounting, therefore making it suitable for comparison to other 'license to practice' professions such as medicine and engineering.

Secondly, to obtain an understanding of the disconnect and/or gap in accounting, an examination of other applied research fields would provide a good basis for a comparison. If, as the anecdotal evidence is indicating, the accounting research has little or no impact on the profession, a comparison of other applied research fields would allow a better analysis of the issues in accounting. Therefore, to fulfil these objectives, practitioners from the professions of accounting, engineering and medicine were targeted with the same questionnaire survey. The selection of engineering and medicine as comparison fields was somewhat subjective, but also based on anecdotal experience. The issue was discussed with researchers from a number of academic fields, and there was a general consensus that medical research was most likely the benchmark for having the most impact on society and practitioners, and that engineering research was perhaps likely to fill the middle ground, somewhere between medicine and accounting. This point of view was supported by the editor of the prestigious journal Administrative Science Quarterly when he argued that emerging fields like accounting and management should model themselves on established disciplines such as engineering and medicine to evaluate their impact on practice [110]. Malmi and Granlund [7] also highlighted the need for accounting research to be evaluated with other applied sciences such as engineering and medicine.

\subsection{Research Questions and Hypotheses}

As discussed at the beginning of Section 2, critical realism (CR) is an ideal philosophy to be utilized when researching an applied phenomenon such as accounting. CR allows the utilization of both quantitative and qualitative methods to be employed, therefore reducing the bias of using a single method, as triangulation of the various data sets helps in the validations of the findings. Using methods from both the positivist and interpretivist paradigms offers an abundance of scientific approaches to be considered. As an example, from the positivist perspective, methods such as cross-sectional studies, experimental studies, longitudinal studies, surveys, database analysis and meta-data analysis could be considered, while on the interpretivist side, action research, case studies, ethnography, feminist perspective, grounded theory, hermeneutics and participative enquiry are all legitimate methodologies. After evaluating what this study was trying to achieve and the design of the research questions/hypotheses, it was decided that an online self-administered survey with both open and closed questions would best meet the requirements of the study. This method allowed the researchers to target a large number of respondents in a relatively low cost and timely manner over a large geographical area, when compared to either face-to-face or telephone interviews. One of the 
key motivations for undertaking this research was to determine if there were significant differences between various professions and their use of academic research. Survey research using Likert scales and regression analysis remains a common method to test for such scientific relationships.

To empirically test the theme being highlighted in this paper, the following research questions and hypotheses are proposed.

RQ1 Is the statement 'that research in academic journals is not utilised by practitioners in professions such as accounting, engineering and medicine' true?

H1.1 The accounting profession does not utilise academic research journals as a source of information on a regular basis (daily/weekly)

H1.2 The engineering profession does not utilise academic research journals as a source of information on a regular basis (daily/weekly)

H1.3 The medical profession does not utilise academic research journals as a source of information on a regular basis (daily/weekly)

RQ2 Is the statement 'there is no difference between professions with respect to reading, using and needing academic material' true?

H2.1 As professions, accountants and engineers do not read academic articles

H2.2 As professions, accountants and engineers do not use academic findings

H2.3 As professions, accountants and engineers do not see a future role for academia

H2.4 As professions, accountants and medical practitioners do not read academic articles

H2.5 As professions, accountants and medical practitioners do not use academic findings

H2.6 As professions, accountants and medical practitioners do not see a future role for academia

RQ3 With respect to understanding and interest in academic articles, how does the accounting profession compare with the other professions?

RQ4 From the perspective of accounting practitioners, what key factors were identified for academia to better meet the needs of the profession?

With limited studies to help guide the methodological design of this study, the research in a sense becomes exploratory. Three methods of data collection are used to acquire an in-depth understanding of how practitioners use academic material: descriptive analyses, quantitative analyses using logistic regression, and qualitative analyses. Rather than the more common multiple regression, the use of logistic regression is justified through two significant reasons. Primarily, there are various questions concerning the dependent variables (DV) that are inherently categorical and not continuous as needed in the analysis for multiple regression. Additionally, it was necessary to create dummy variables for independent variables (IV), as the number of accountants using academic material was small, and in doing so, has enabled a much more purposeful analysis of collected data.

\subsection{Dependent and Independent Variables}

There are three hypotheses affiliated with the first research question in which the dependent variable profession is individually tested against nine independent variables (information sources). Using accounting practitioners as one of the professions, the dependent variable is considered a dichotomous variable, with (0) being nominated for information not sourced regularly, and (1) for information sourced regularly. The data reference for 'not sourced regularly' refers to the periods: monthly/yearly/never, while 'sourced regularly' covers the periods: daily/weekly. Nine information sources constitute the set of independent variables, namely: research journals; conferences/workshops; colleagues; newspapers; in-house courses; professional bodies; industry standards; technical bulletins; and magazines. To test for significant relationships between accounting practitioners and the nine information sources, logistic regression was utilized. The two other professions underwent the same regression testing. 
While the first research question is designed to analyze relationships between each individual profession and sources of information, the purpose of the second research question is to identify differences between professions with respect to the use and need of academic material. For this set of hypotheses, the data from the three professions are combined and analyzed as a single data set. To analyze differences, three dependent variables are tested against several generic independent variables including professions. The three dependent variables are read academic articles, use academic findings, and future role of academia. Again, these three DVs became dichotomous variables with read academic articles taking the value of ' 1 ' if academic articles are read on a sometimes/regular basis and ' 0 ' if read on a rarely/never basis. The time period for 'sometimes/regular basis' includes daily, weekly and monthly, with rarely/never being yearly and never. The second DV use academic findings follows the same period splits as for the first DV with ' 1 ' representing the use of academic findings on a sometimes/regular basis, and ' 0 ' rarely/never. For the third DV, future role of academic ' 1 ' was assigned to those who agree/strongly agree in a future role for academic, and ' 0 ' otherwise.

For the six independent variables, each were converted to dummy variables and arranged as the following. For Gender , ' 1 ' was assigned to male and ' 0 ' to female; Qualifications ' 1 ' was assigned to postgraduate and ' 0 ' to undergraduate; and Experience ' 1 ' was assigned $>30$ years and ' 0 ' $<30$ years. The size of firm (Firm size) was based on the number of employees and the data was sorted according: for accounting ' 1 ' was assigned $>5$ employees and ' 0 ' $<5$ employees; for engineering ' 1 ' was assigned $>100$ employees and ' 0 ' $<100$ employees; and for medical ' 1 ' was assigned $>10$ employees and ' 0 ' $<10$ employees. For the professions, Engineering takes the value of ' 1 ' as the Interest category and ' 0 ' is assigned to accounting/medical practitioners as the Reference category. For the Medical variable, medical practitioners take the value of ' 1 ' as the Interest category and ' 0 ' is assigned to accounting/engineering practitioners as the Reference category.

\subsection{Survey Design}

Despite attempts to find a validated and published survey, the search did not yield a suitable sample. Therefore, as this is a new survey, it is necessary to highlight the steps taken to satisfy issues involving reliability and validity. To ensure the validity of the survey answers, measures related to the development and design of surveys were undertaken [111-113]. Next, the survey and research questions underwent evaluation by several experts with experience in survey design. Finally, a pilot study was conducted on the three target groups to test and receive feedback on the new survey.

To test for reliability, Cronbach's alpha was used to statistically test the reliability of measures being applied within the scale. Research in the social sciences utilizing Cronbach's alpha deems values of 0.7 and above to be reliable [114,115]. For this study, the four coefficients obtained for each were 0.77 (Accounting); 0.80 (Engineering); 0.77 (Medicine) and 0.83 (Combined).

The questionnaire survey was organized into three distinct segments. The first segment covered the demographics of participants, while the second segment explored how practitioners keep up to date within their professions. The final segment investigated practitioners' interest in research article titles. The second segment was designed to ascertain data on sourced information, where it come from, what type, and how often sort. For the final segment, participants were shown around 16 research article titles and asked to record their level of understanding of the title and interest to read the article. The article titles for each profession were selected from Web of Science and Scopus journals, with the focus being on the most cited articles since 1980.

Before the official survey started, the questionnaire was distributed to a number of randomly selected practitioners within each profession. The pilot study was beneficial because it highlighted some areas in the questionnaire which needed improvement. Once the pilot study was complete, over 4000 surveys were emailed to practitioners, with a cover letter and link to online questionnaire, and 560 were completed, providing a response rate of nearly $14 \%$. The summary of participants is shown in Table 2. A descriptive breakdown of the 560 participants can be viewed in Table 3 . 
Table 2. Survey response overview.

\begin{tabular}{lcccc}
\hline Profession & Returns (n) & Return Rate & Information Source & Female Rate \\
\hline Accounting & 198 & $14 \%$ & $\begin{array}{c}\text { CA-61\% } \\
\text { CPA-39\% }\end{array}$ & $21 \%$ \\
\hline Engineering & 244 & $17 \%$ & Engineers Australia & $5 \%$ \\
\hline Medicine & 118 & $9 \%$ & Yellow Pages & $34 \%$ \\
\hline Totals & 560 & $14 \%$ & - & $17 \%$ \\
\hline
\end{tabular}

Table 3. Descriptive statistics of participants $(n=560)$.

\begin{tabular}{|c|c|c|c|}
\hline Variable & Accounting $(n=198)$ & Engineering $(\mathrm{n}=244)$ & Medicine $(\mathrm{n}=118)$ \\
\hline \multicolumn{4}{|l|}{ Gender } \\
\hline Male & $79 \%$ & $95 \%$ & $66 \%$ \\
\hline Female & $21 \%$ & $5 \%$ & $34 \%$ \\
\hline \multicolumn{4}{|l|}{ Age } \\
\hline$<30$ & $3 \%$ & $4 \%$ & $3 \%$ \\
\hline $30-39$ & $15 \%$ & $19 \%$ & $18 \%$ \\
\hline $40-49$ & $28 \%$ & $18 \%$ & $23 \%$ \\
\hline $50-59$ & $34 \%$ & $27 \%$ & $38 \%$ \\
\hline$>59$ & $20 \%$ & $32 \%$ & $18 \%$ \\
\hline \multicolumn{4}{|l|}{ Qualification } \\
\hline Diploma & $5 \%$ & $2 \%$ & - \\
\hline Bachelor & $44 \%$ & $48 \%$ & $31 \%$ \\
\hline Masters & $18 \%$ & $33 \%$ & $10 \%$ \\
\hline PhD & $0 \%$ & $10 \%$ & $11 \%$ \\
\hline Other Post Grad & $33 \%$ & $7 \%$ & $48 \%$ \\
\hline \multicolumn{4}{|l|}{ Experience (years) } \\
\hline$<5$ & $2 \%$ & $1 \%$ & $4 \%$ \\
\hline $5-14$ & $13 \%$ & $18 \%$ & $19 \%$ \\
\hline $15-30$ & $50 \%$ & $37 \%$ & $44 \%$ \\
\hline$>30$ & $35 \%$ & $44 \%$ & $33 \%$ \\
\hline \multicolumn{4}{|l|}{ Firm size (employees) } \\
\hline$<5$ & $41 \%$ & $17 \%$ & $24 \%$ \\
\hline $5-20$ & $38 \%$ & $8 \%$ & $43 \%$ \\
\hline $21-50$ & $7 \%$ & $3 \%$ & $33 \%(>20)$ \\
\hline $51-100$ & $2 \%$ & $9 \%$ & \\
\hline$>100$ & $12 \%$ & $63 \%$ & \\
\hline \multicolumn{4}{|l|}{ Firm scope } \\
\hline Local & $75 \%$ & $21 \%$ & \\
\hline National & $11 \%$ & $30 \%$ & $\mathrm{~N} / \mathrm{A}$ \\
\hline International & $14 \%(\operatorname{Big} 4-10 \%)$ & $49 \%$ & \\
\hline \multicolumn{4}{|l|}{ Position in firm } \\
\hline Junior level & $1 \%$ & $0 \%$ & $72 \%$ (Consulting) \\
\hline Middle level & $3 \%$ & $27 \%$ & 22\% (Principal) \\
\hline Senior level & $96 \%$ & $73 \%$ & $6 \%$ (Sole practice) \\
\hline \multicolumn{4}{|l|}{ Field of work } \\
\hline & $5 \%$-Financial & $17 \%$-Mechanical & $50 \%$-General (GP) \\
\hline & $6 \%$-Management & $13 \%$-Electrical & $50 \%$-Specialist \\
\hline & $5 \%$-Auditing & $41 \%$ - Civil & \\
\hline & $54 \%-\mathrm{Tax}$ & $9 \%$-General & \\
\hline & $19 \%$-General & $20 \%$-Other & \\
\hline & $11 \%$-Other & & \\
\hline \multicolumn{4}{|l|}{ Professional membership } \\
\hline & $\begin{array}{l}38 \% \text {-Certified Practising } \\
\text { Accountants (CPA) }\end{array}$ & 97\%—Engineers Australia (EA) & $\begin{array}{l}44 \% \text {-Australian Medical } \\
\text { Association (AMA) }\end{array}$ \\
\hline & $\begin{array}{l}65 \% \text {-Institute of Chartered } \\
\text { Accountants (CA) }\end{array}$ & $\begin{array}{l}10 \% \text {-Association of Consulting } \\
\text { Engineers Australia (ACEA) }\end{array}$ & $\begin{array}{l}44 \% \text {-Royal College of } \\
\text { General Practitioners } \\
\text { (RACGP) }\end{array}$ \\
\hline & $\begin{array}{l}4 \% \text {-Institute of Public } \\
\text { Accountants (IPA) }\end{array}$ & $\begin{array}{l}1 \% \text {-Institution of Engineering } \\
\text { and Mining Surveyors Australia } \\
\text { (IEMSA) }\end{array}$ & $\begin{array}{l}13 \% \text {-Royal Australasian } \\
\text { College of Surgeons (RACS) }\end{array}$ \\
\hline & $20 \%$-Other & $34 \%$ - Other & $49 \%$-Other \\
\hline & $1 \%$-None & & $4 \%$-None \\
\hline
\end{tabular}


With respect to sources used to randomly select participants, accountants were chosen from the two major accounting bodies: Certified Practising Accountants (CPA Australia) and the Institute of Chartered Accountants in Australia (CA Australia). For engineers, the peak body representing the engineering profession was utilized: Engineers Australia. For medical practitioners, the task of targeting the doctor directly was difficult due to the fact that the majority of general practitioners/medical specialists operated under the umbrella of medical centers or clinics. This meant that emails sent to doctors were under the very real possibility of being filtered by the clinics support staff. This filtering impact may be a reason for the lower response rate of medical practitioners compared to accountants and engineers who were addressed directly. The survey coverage targeted the five biggest cities in Australia, which represent nearly 70 percent of the total population in Australia.

\section{Results}

\subsection{Accountants' Utilization of Academic Research Journals}

\subsubsection{Descriptive Analyses}

A comparison between the professions and how regularly they read professional material is presented in Table 4. The survey differentiated the data into two sections; newspapers, profession-related bulletins and professional magazines (NA-Non-Academic), and academic articles and research journals (A-Academic). The table clearly demonstrates distinct differences between the professions with respect to the two types of reading material. Combining the daily and weekly frequency rates, around $60 \%$ of accountants read non-academic material on a weekly basis, while for engineers, the figure is $51 \%$, and for medicine $84 \%$. For academic material, only $4 \%$ of accountants read on a weekly basis, while for engineering and medicine, the rates are $13 \%$ and $59 \%$ respectively.

Table 4. Practitioners' reading of professional material: Non-Academic (NA) vs. Academic (A).

\begin{tabular}{lcccccccccc}
\hline \multirow{2}{*}{ Profession } & \multicolumn{2}{c}{ Daily } & \multicolumn{2}{c}{ Weekly } & \multicolumn{2}{c}{ Monthly } & \multicolumn{2}{c}{ Yearly } & \multicolumn{2}{c}{ Never } \\
\cline { 2 - 11 } & NA & A & NA & A & NA & A & NA & A & NA & A \\
\hline Accounting & $20 \%$ & $0 \%$ & $41 \%$ & $4 \%$ & $34 \%$ & $17 \%$ & $3 \%$ & $28 \%$ & $2 \%$ & $51 \%$ \\
\hline Engineering & $6 \%$ & $1 \%$ & $45 \%$ & $12 \%$ & $46 \%$ & $43 \%$ & $3 \%$ & $33 \%$ & $0 \%$ & $11 \%$ \\
\hline Medicine & $34 \%$ & $14 \%$ & $50 \%$ & $45 \%$ & $16 \%$ & $33 \%$ & $0 \%$ & $5 \%$ & $0 \%$ & $3 \%$ \\
\hline
\end{tabular}

When the data are combined up to a monthly basis, the gap with respect to reading academic material increases significantly for accounting when compared to the other two professions. For accountants, the frequency of reading academic material on at least a monthly basis is $21 \%$, while for engineers, it is $56 \%$ and medicine is $92 \%$. On the other end of the scale, $51 \%$ of accountants never read academic material, while the figures drop to $11 \%$ for the engineering profession and $3 \%$ for medicine.

To better understand some of the reasons why accountants don't or rarely read academic research articles, Table 5 is provided. Three of the top four reasons identified relate to the 'content' of academic articles, such as; 'not related to their work', 'not interesting', and 'written for academics not practitioners'. With regards to the level of 'academic' language used within accounting research articles, language is not considered a barrier, with only $6 \%$ indicating that they did not understand the language used in articles. Interestingly, his percentage was lower than for both the engineers (7\%) and medical practitioners $(9 \%)$. 
Table 5. Reasons why participants do not or rarely read academic research articles.

\begin{tabular}{lccc}
\hline \multicolumn{1}{c}{ Reason } & Accounting & Engineering & Medicine \\
\hline Content is not related to my work & $45 \%$ & $47 \%$ & $27 \%$ \\
Content is written for academics not practitioners & $41 \%$ & $41 \%$ & $33 \%$ \\
Do not have access to academic articles & $38 \%$ & $44 \%$ & $21 \%$ \\
Content is not interesting & $21 \%$ & $18 \%$ & $21 \%$ \\
Journal subscription costs are too high & $12 \%$ & $25 \%$ & $24 \%$ \\
Other & $11 \%$ & $17 \%$ & $52 \%$ \\
Cannot understand language used in academic & $6 \%$ & $7 \%$ & $9 \%$ \\
articles & & & \\
\hline
\end{tabular}

Participants could choose more than one reason.

\subsubsection{Logistic Regression Analyses}

Associated with RQ1 are three hypotheses, and logistic regression is used to identify significant relationships. To distinguish significant relationships, all three groups of practitioners (DV) are evaluated against the nine information sources (IV), as presented in Table 6. Each profession was asked to indicate the level that they regularly use each sources of information. For each of the professions, the requirements for the model fit were met. For accounting practitioners, the Omnibus Tests of Model Coefficients was significant at 0.008 , with 22.322 being the chi-square value and the degrees of freedom being nine. This test provides an indication of whether the new model (with predictor variables included) is an improvement over the baseline model. It uses chi-square tests to see if there is a significant difference between the Log-likelihoods (specifically the -2LLs) of the baseline model and the new model. This is referred to as a 'goodness of fit' test and the desired result is a highly significant value (the Sig. value should be less than 0.05). To further analyze how well the data fit the model, another 'goodness of fit' test, the Hosmer and Lemeshow test, is used. For this test, the chi-square is 12.625 with a significance of 0.125 , therefore adding further support for the model. This test, which for SPSS, is the most reliable test of model fit available in SPSS [115], is interpreted very differently from the omnibus test discussed above. For the Hosmer-Lemeshow test, a highly significant value of 'goodness of fit' indicates a poor model fit, therefore, the desired outcome is a value greater than 0.05 . Additionally, $\mathrm{R}$ square values are another form of evidence to validate the strength of the model. When using logistic regression, these values are presented as pseudo $R$ square statistics, unlike in multiple regression, which relies on real R square values. Nagelkerke R square (0.161) and Cox and Snell R square (0.119) represent the two pseudo R square tests, which in turn demonstrate the degree of variation in the dependent variable when tested against the independent variables applied in the model. Values range between 0 to 1 and for the two R square values obtained ( 0.119 and 0.161$)$; this suggests that between 11.9 percent and 16.1 percent of the variability is explained by the set of variables under study.

The omnibus test of model coefficients for engineering is 0.000 , with 70.043 being the chi-square value and the degrees of freedom being nine. For the Hosmer and Lemeshow test, the chi-square is 17.789 at a significance level of 0.230 . To explain the variation in the DV due to the group of IVs used, Nagelkerke R square indicated that 35.7\% (0.357) was explained, while for Cox and Snell R square, $26.8 \%(0.268)$ was clarified. In the case of medical practitioners, the omnibus test of model coefficients is 0.001 , with 28.268 being the chi-square value and the degrees of freedom being nine. For the Hosmer and Lemeshow test, the chi-square is 9.642 at a significance level of 0.291 . To explain the variation in the DV due to the group of IVs used, Nagelkerke R square recorded 31\% (0.310) being explained, while for Cox and Snell R square, $22.3 \%$ (0.223) was clarified.

The results for hypotheses proposed for RQ 1 are presented in Table 6 . The proposed hypotheses anticipate that practitioners do not seek knowledge or information from academic sources regularly. What is being implied is that the variable profession is independent of variable research journals and no relationship will be found between these variables. For the first hypothesis (H1.1) involving the accounting profession, there exists a weak outcome, as the data collected do not disprove the null 
hypothesis. Therefore, the result for this hypothesis could be understood in separate ways. The null hypothesis can be considered either true or false as the data did not offer any conclusive outcome; or it can be interpreted that there is no indication to change from the current hypothesized position. Further to this outcome, the relationship between accountants and their use of academic research had a high non-significant value ( $p=0.851)$, therefore implying that the null hypothesis had a higher probability of being true than false. With respect to accountants sourcing information regularly, Magazines were the only substantial relationship $(p=0.002)$.

Table 6. Sources used on a regular basis: Comparison of the three professions.

\begin{tabular}{|c|c|c|c|c|c|c|c|c|c|}
\hline \multirow{3}{*}{$\begin{array}{l}\text { Sources Used on a } \\
\text { Regular Basis }\end{array}$} & \multicolumn{9}{|c|}{ Professions } \\
\hline & \multicolumn{3}{|c|}{ Accounting } & \multicolumn{3}{|c|}{ Engineering } & \multicolumn{3}{|c|}{ Medicine } \\
\hline & B & Sig. & $\operatorname{Exp}(B)$ & B & Sig. & $\operatorname{Exp}(B)$ & B & Sig. & $\operatorname{Exp}(B)$ \\
\hline $\begin{array}{l}\text { Industry Standards } \\
\text { (Government bodies) }\end{array}$ & -0.235 & 0.571 & 0.790 & 0.287 & 0.399 & 1.332 & -1.087 & 0.092 & 0.337 \\
\hline Magazines & 1.150 & 0.002 & 3.158 & 1.405 & 0.000 & 4.075 & 0.003 & 0.996 & 1.003 \\
\hline Newspapers & -0.354 & 0.364 & 0.702 & 0.462 & 0.192 & 1.587 & 0.353 & 0.543 & 1.423 \\
\hline Research journals & -0.148 & 0.851 & 0.863 & 1.322 & 0.028 & 3.751 & 1.293 & 0.013 & 3.643 \\
\hline Colleagues & -0.013 & 0.972 & 0.987 & 0.590 & 0.075 & 1.803 & -0.129 & 0.806 & 0.879 \\
\hline $\begin{array}{l}\text { In-house courses } \\
\text { (Drug companies) }\end{array}$ & -0.247 & 0.506 & 0.781 & 0.104 & 0.799 & 1.109 & -2.147 & 0.007 & 0.117 \\
\hline $\begin{array}{l}\text { Technical bulletins } \\
\text { (Medical bulletins) }\end{array}$ & 0.566 & 0.119 & 1.761 & 1.435 & 0.000 & 4.200 & 2.526 & 0.000 & 12.498 \\
\hline Conferences/workshops & 0.155 & 0.681 & 1.168 & -0.064 & 0.871 & 0.938 & 0.221 & 0.674 & 1.248 \\
\hline Professional bodies & 0.422 & 0.272 & 1.524 & 0.064 & 0.862 & 1.067 & -0.312 & 0.570 & 0.732 \\
\hline
\end{tabular}

( ) Brackets denote terminology used in medical survey.

The second hypothesis (H1.2), predicting that the engineering profession did not utilize research from academia, was rejected, as a significant relationship $(p=0.028)$ was found between the two. Therefore, with the null hypothesis rejected, then it can be stated, to a confidence level of $95 \%$, that the alternative hypothesis is true, predicting that engineers do make use of research from academia regularly. Other significant sources of information for the engineering practitioners were Technical Bulletins $(p=0.000)$ and Magazines $(p=0.000)$.

The third hypothesis (H1.3) predicting that the medical profession does not utilize research from academia was rejected, as a significant relationship $(p=0.013)$ was found between the two. Therefore, with the null hypothesis rejected, then it can be stated, to a confidence level of $95 \%$, that the alternative hypothesis is true, predicting that the medical profession does make use of research from academia regularly. Information from Drug Companies $(p=0.007)$ and Medical Bulletins $(p=0.000)$ was found to be a significant source for medical practitioners.

\subsection{Comparison between Professions Regards Reading, Using and Future Need for Academic Material}

\subsubsection{Descriptive Analyses}

Table 7 illustrates a comparison of practitioners needed for research in their jobs and organizations, including the future role for research. Points of note from these figures include the first inquiry, where $41 \%$ of accountants believe it is important to have access to the current research to undertake their professional duties. When the inquiry is narrowed from 'research' to the need for 'academic research' in their workplace (inquiry 2 and 3), the support for academic research greatly reduces. This decline of support for academic research by accountants is also very evident when contrasted against the other two professions. While this study did not determine what forms of current research accountants were accessing, the situation could be viewed in a couple of ways. Firstly, due to the lag period for academic research to be published, accounting practitioners may feel that the research is no longer current or relevant. Another issue is the fact that many accounting practitioners do not 
believe that academic research is designed and/or targeted for accountants. This point is highlighted in the qualitative analyses for Research Question 4. The fourth inquiry in Table 7 explores the issue of whether organizations provide their professional staff with suitable access to research resources. Regarding this point, it would seem to be having a limited impact with the levels of dissatisfaction falling within the narrow range of $11 \%$ to $19 \%$ for all three professions.

Table 7. Practitioners current and future need for academic research.

\begin{tabular}{lccc}
\hline \multicolumn{1}{c}{ Inquiry } & Accounting & Engineering & Medicine \\
\hline $\begin{array}{l}\text { It is important to keep up with the latest research to do } \\
\text { my job }\end{array}$ & $41 \%$ & $75 \%$ & $93 \%$ \\
\hline I have used findings from academic research in my job & $17 \%$ & $64 \%$ & $90 \%$ \\
\hline $\begin{array}{l}\text { Colleagues and I discuss recent academic } \\
\text { research findings }\end{array}$ & $12 \%$ & $48 \%$ & $85 \%$ \\
\hline $\begin{array}{l}\text { My organization does not provide me with adequate } \\
\text { access to sources of relevant research material }\end{array}$ & $17 \%$ & $19 \%$ & $11 \%$ \\
\hline $\begin{array}{l}\text { I believe there are still many unanswered questions to } \\
\text { be addressed in my profession }\end{array}$ & $36 \%$ & $88 \%$ & $98 \%$ \\
\hline $\begin{array}{l}\text { I believe academic research will play an important role } \\
\text { in the future development and improvement of } \\
\text { my profession }\end{array}$ & $22 \%$ & $70 \%$ & $93 \%$ \\
\hline
\end{tabular}

The final two inquiries in Table 7 take a futuristic perspective of continuing issues in the respective professions and the likely role of academic research. These inquiries are formulated in a way to garner the level of unfulfilled knowledge in all three professions, and whether academic research has a significant role in minimizing these gaps and aiding in the progression of the professions' future. The results of these two inquiries indicate the large gap which exists between the accounting profession and the practitioners from the engineering and medical professions. Only 36 percent of accountants believe that there remain unanswered questions in the profession while for engineering and medicine the figure is around 90 percent. With respect to the role of academic research on developing and improving the profession in the future, less than 1 in 4 accountants were positive about such a future prospect. This significantly differs from the nearly 3 in 4 for engineering and over 90 percent for medicine. These differences are significant, as is shown in the hypotheses testing for RQ 2.

\subsubsection{Logistic Regression Analyses}

To test the hypotheses proposed under RQ 2, the data are combined $(n=560)$ and three dependent variables are tested in three separate logistic regression models (refer to Table 8). The three DVs are; read academic articles, use academic findings, and future role of academia. The independent variables used for each model included four generic variables; gender, qualifications, experience and firm size, and the three professions.

With respect to each dependent variable, the model fit conditions were met. The omnibus test of model coefficients for read academic articles is 0.000 , with 146.662 being the chi-square value and 146.662 and the degrees of freedom being six. Adding further support to the 'goodness of fit' test above is the Hosmer and Lemeshow test with a chi-square value of 7.974 and a significance of 0.436 , keeping in mind that significance values need to be greater than 0.05 for this test. Additional details about the strength of the model are indicated by two R square values, Nagelkerke R square (0.320), Cox and Snell R square (0.240). To explain the variation in the DV due to the group of IVs used in this model, Nagelkerke R square indicated that 32.0\% (0.320) was explained, while for Cox and Snell R square, $24.0 \%(0.310)$ was clarified. 
Table 8. Analysis of data combining the three professions.

\begin{tabular}{|c|c|c|c|c|c|c|c|c|c|}
\hline \multirow{2}{*}{ Variables } & \multicolumn{3}{|c|}{$\begin{array}{l}\text { Read Academic Articles } \\
\text { (Monthly or More) }\end{array}$} & \multicolumn{3}{|c|}{$\begin{array}{l}\text { Use Academic Findings } \\
\text { (Monthly or More) }\end{array}$} & \multicolumn{3}{|c|}{$\begin{array}{l}\text { Future Role of Academia } \\
\text { (Agree/Strongly Agree) }\end{array}$} \\
\hline & B & Sig. & $\operatorname{Exp}(B)$ & B & Sig. & $\operatorname{Exp}(B)$ & B & Sig. & $\operatorname{Exp}(B)$ \\
\hline $\begin{array}{l}\text { Gender } \\
\text { (Male) }\end{array}$ & -0.245 & 0.421 & 0.783 & 0.357 & 0.291 & 1.429 & 0.234 & 0.483 & 1.264 \\
\hline $\begin{array}{l}\text { Qualifications } \\
\text { (Postgraduate) }\end{array}$ & 0.781 & 0.000 & 2.184 & 0.717 & 0.001 & 2.048 & 0.474 & 0.030 & 1.607 \\
\hline $\begin{array}{l}\text { Experience } \\
\text { (>30 years) }\end{array}$ & 0.011 & 0.960 & 1.011 & 0.160 & 0.483 & 1.173 & 0.159 & 0.489 & 1.172 \\
\hline Firm/practice size & -0.212 & 0.382 & 0.809 & 0.079 & 0.755 & 1.082 & -0.294 & 0.276 & 0.745 \\
\hline \multicolumn{10}{|l|}{ Professions } \\
\hline Accounting & 0 & 0 & 0 & 0 & 0 & 0 & 0 & 0 & 0 \\
\hline Engineering & 1.430 & 0.000 & 4.180 & 2.080 & 0.000 & 8.006 & 2.232 & 0.000 & 9.317 \\
\hline Medicine & 3.138 & 0.000 & 23.050 & 3.717 & 0.000 & 41.158 & 4.018 & 0.000 & 55.575 \\
\hline
\end{tabular}

The omnibus test of model coefficients for use academic findings is 0.000, with 198.043 being the chi-square value and the degrees of freedom being six. For the Hosmer and Lemeshow test, the chi-square is 5.128 at a significance level of 0.744 . To explain the variation in the DV due to the group of IVs used, Nagelkerke R square indicated $41.3 \%$ (0.413) was explained, while for Cox and Snell R square, $31.0 \%(0.310)$ was clarified. For the future role of academia, the omnibus test of model coefficients is 0.000 , with 195.241 being the chi-square value and the degrees of freedom being six. For the Hosmer and Lemeshow test, the chi-square is 6.156 at a significance level of 0.522 . To explain the variation in the DV due to the group of IV's used, Nagelkerke R Square recorded $41.2 \%(0.412)$ being explained, while for Cox and Snell R square, 30.6\% (0.306) was clarified.

To answer the hypotheses associated with Research Question 2 (RQ 2), Table 8 is presented. The table provides the regression findings when the combined data for the three professions are analyzed. The six hypotheses predict that there will be no significant differences between the professions with respect to reading academic articles, using academic findings and a future role for academia. To analyze the three professions against each of the dependent variables (read academic articles, use academic findings, and future role of academia), two dummy variables are setup, one isolating medical data and the other isolating engineering data, with accounting data acting as a constant in both variables. The first three hypotheses ( $\mathrm{H} 2.1$ to $\mathrm{H} 2.3$ ) compare the accounting profession against the engineering profession for each dependent variable. The last three hypotheses (H2.4 to H2.6) compare the accounting profession against the medical profession for each dependent variable.

The first hypothesis (H2.1), predicting that accountants and engineers do not read academic articles, was found to be not true, as the relationship between the two groups was significant $(p=0.000)$. Rejecting the null hypothesis allows the alternative hypothesis to be considered at a confidence level of $95 \%$. This means that engineering practitioners do read academic articles on a reasonably regular basis when compared with accountants. With respect to the first two DVs (read academic articles and use academic findings), the term 'reasonably regular' refers to frequency periods of daily, weekly and monthly.

For the second hypothesis (H2.2), predicting that accountants and engineers do not use academic findings, was found to be not true, as the relationship between the two groups was significant $(p=0.000)$. Rejecting the null hypothesis allows the alternative hypothesis to be considered at a confidence level of $95 \%$. This means that engineering practitioners do use academic findings on a reasonably regular basis when compared with accountants. For the third hypothesis (H2.3), predicting that accountants and engineers do not recognize a future role for academia, was found to be not true, as the relationship between the two groups was significant $(p=0.000)$. Rejecting the null hypothesis allows the alternative hypothesis to be considered at a confidence level of $95 \%$. This means that engineering practitioners do believe that there is a future for academia in their profession when compared with accountants. 
The fourth hypothesis (H2.4), predicting that accountants and medical practitioners do not read academic articles, was found to be not true, as the relationship between the two groups was significant $(p=0.000)$. Rejecting the null hypothesis allows the alternative hypothesis to be considered at a confidence level of $95 \%$. This means that medical practitioners do read academic articles on a reasonably regular basis when compared with accountants.

For the fifth hypothesis (H2.5), predicting that accountants and medical practitioners do not use academic findings was found to be not true, as the relationship between the two groups was significant $(p=0.000)$. Rejecting the null hypothesis allows the alternative hypothesis to be considered at a confidence level of $95 \%$. This means that medical practitioners do use academic findings on a reasonably regular basis when compared with accountants. For the last hypothesis (H2.6), predicting that accountants and medical practitioners do not recognize a future role for academia, was found to be not true, as the relationship between the two groups was significant $(p=0.000)$. Rejecting the null hypothesis allows the alternative hypothesis to be considered at a confidence level of $95 \%$. This means that medical practitioners do believe that there is a future for academia in their profession when compared with accountants.

While both engineering and medical practitioners were found to be significantly different to accountants with respect to their professions positive use and future reliance on academia, it should be noted that the impact of this difference is much greater in the medical profession than for engineering. As shown in the $\operatorname{Exp}(\mathrm{B})$ column, the odds ratios for medicine have over five times the impact as for engineering for each DV when the value of the predictor increases by one unit. From the other predictors (gender, qualifications, work experience and firm size) used in the modelling only one is shown to have a significant impact. In all three dependent variables modelled (read academic articles, use academic findings, and the future role of academic), having a postgraduate qualification was found to be positively significant $(p<0.05)$.

\subsection{Comparison of Understanding and Interest in Academic Research Articles}

While the focus of the first two research questions is to explore the use of academic material, RQ 3 attempts to analyze practitioners' understanding of titles given to popular academic research articles in their field, along with practitioners' interest to read these popular articles. Participants were asked to rate their 'understanding of title' and 'interest to read' from a list of popular journal article titles (refer to Table 9). For accountants, the titles of 16 popular academic research articles were presented from four key accounting fields: management accounting; financial accounting; auditing and accountability; and taxation accounting. One reason to undertake such testing is because within the world of practice, it is not unusual to hear criticism about the difficulty to understand the meaning of titles given to academic articles, and even within academic circles, some article titles can be challenging to get some form of appreciation of the article's content.

Table 9. Understanding and interest of the most cited academic journal articles.

\begin{tabular}{|c|c|c|c|c|}
\hline \multirow{2}{*}{ Profession } & \multirow{2}{*}{$\begin{array}{l}\text { From the Title I Have a } \\
\text { Good Idea of What the } \\
\text { Article Is About }\end{array}$} & \multirow{2}{*}{$\begin{array}{c}\text { I Would Be } \\
\text { Interested to Read } \\
\text { This Article }\end{array}$} & \multicolumn{2}{|c|}{ Exposure to Academic Articles } \\
\hline & & & $\begin{array}{c}\text { Read } \\
\text { Daily/Weekly/Monthly }\end{array}$ & Never Read \\
\hline Accounting & $52 \%$ & $25 \%$ & $21 \%$ & $51 \%$ \\
\hline Engineering & $39 \%$ & $24 \%$ & $56 \%$ & $11 \%$ \\
\hline Medicine & $81 \%$ & $51 \%$ & $92 \%$ & $3 \%$ \\
\hline
\end{tabular}

With respect to 'popular' academic articles titles used in this study, databases such as Scopus and Web of Science were utilized to provide a listing of the most cited articles titles since 1979 for each profession, and these most sited titles were presented to practitioners. As is shown in Table 9, just over half the accountants indicated that they had a reasonably good understanding of the titles 
presented, which was higher than for engineers (38.8\%), but much lower than medical practitioners, which recorded just over $80 \%$.

To provide further evidence on how 'popular' these most cited academic article titles were with practitioners, a second question was asked whether participants would be interested to read the articles. While half of the accountants understood the titles, only $25 \%$ indicated an interest in reading the article. While only 1 in 4 practitioners wanting to read the most cited articles could maybe be considered low, it could also be argued that many of the most cited articles presented are getting dated, and that in fact, many practitioners may be more interested in reading about more contemporary or future issues related to their profession.

The following provides some qualitative information on the popularity of the 16 accounting article titles presented in this study. The three most understandable titles rated by participants were:

1. 'The role of budgets in organizations facing strategic change: An exploratory study'

2. 'Determinants of tax evasion: A cross-country investigation'

3. 'Audit committee, board of director characteristics, and earnings management'

The three least understandable titles rated by participants were:

1. 'The role of actor-networks and boundary objects in management accounting change: A field study of an implementation of activity-based costing'

2. 'Management accounting systems, perceived environmental uncertainty and organization structure: An empirical investigation'

3. 'Empirical tax research in accounting'

With respect to participants' interest in wanting to read the most cited articles, the two highest rated articles were the same as the top two most understandable articles selected above, except that 1 and 2 were reversed. The third most interested to read article was: 'The use of financial accounting choice to support aggressive tax positions: Public and private firms'. Articles that participants were least interested in reading were the same as the first two least understandable articles listed above. The third least interested article to read was: 'Accounting, auditing and corporate governance of European listed countries: EU policy developments before and after Enron'.

\subsection{Identified Factors Academia Could Better Meet the Needs of Practitioners and the Accounting Profession}

$\mathrm{RQ} 4$ is qualitative in nature and examines the written comments by accounting practitioners. The survey offered participants the opportunity to provide written feedback on how academic research could better meet the needs of practitioners. Using the themes identified in the literature review, the content of each written response was scanned and coded, with theme keywords being highlighted within the text. After coding, the written content was analyzed to identify popular themes, including subset content within each theme. The analyses highlighted three key areas: Issues, Engagement, and Dissemination, and these areas with subset content are summarized below.

Issues

- Complying with ASIC's 'one size fits all' rules for all types of companies is not logical

- Micro and small businesses need to comply with same accounting/audit rules as large and multinational firms

- Accounting Standards need to be simplified

- Research needs to be relevant to accountants, not just academics

- Research articles need to be written in commonly used English

- Academic research should explain how theory relates/improves accounting practice 
Engagement

- Academics need to build stronger research links with ASIC and professional accounting bodies

- Academics need to talk to practitioners to better understand contemporary issues

- Invite practitioners to participate in research

Dissemination

- Provide summaries of university research in professional accounting magazines

- Develop information mechanism that utilize digital and social media networks

- Academic research should be accessed free and electronically

To give some understanding of the context from which the factors above were determined, a small sample of selected direct quotes from accounting participants have been included below.

There is too much 'research' just for the sake of research—to keep academics employed. Changes happen, and then 5 years later, they change back to what they were (e.g., balance sheet becoming 'Statement of Financial Position', then changing back again). Academics are totally out of touch with what the people that use the information want. Forget about accountants-what do the public want? After all, they should be the main users of the accountants' output-not other accountants.

Maybe academic research could be used to point out the absurdities of some of the current laws and the complex web that these laws create. It is ridiculous that we have a tax and legal system where the standard answer to a client's question is 'there's no simple answer'.

Distinguish the relevance between large corporate accounting matters/policies/guidelines and small business accounting. Same for auditing - there should be classes of auditors to allow more lenient qualifications/experience for small audits vs. audits of large firms. At the moment, it is a one size fits all for registered company auditors.

Make sure it is practical. I understand the need for theoretical research. Good research solves problems, great research prevents problems. This survey is a great start. Start engaging practitioners; faculties should have coffee catch ups on research and curricular. I am tired of training grads on basic stuff that university courses say they cover and we have to pay high salaries for pieces of paper that do not deliver. Get practitioners involved in guest lecturing and listen to their comments to students. Students will respect the research and will better assist in development. Research is sometimes viewed as a self-interested pursuit. Researchers can get lost in their bubble. The idea is to solve real problems. It is more important to ask the right questions than get the right answer first. I think that the way in which research topic titles present themselves is often esoteric and uninspiring. You do not want to read any further because it does not sound like any practical solutions will come out of a paper. It is more of a debate which is important, but it needs to be more practical in its conclusions. If accounting research does not inspire owners/boards for change, then it is a waste of time. You cannot regulate change; self-regulation works better if the change that is required to generate this momentum is clear.

Get into publications we read-I could not even name an academic referred journal for accounting. Get over the precious formatting of scientific journals and write for your users. People who are interested in your scientific/statistical methodology (who are generally only other academics) will look it up; those of us trying to put things into practice couldn't care less about the sample size, just effective outcomes. Stop repeating and duplicating meaningless research, find out what we need to know in the real world BEFORE starting your research. 
Maybe they are asking other parts of the firm, but I have never been asked for my input or thoughts on a piece of academic research.

Better access through web-based materials and newsletters. We don't know what is being researched.

The research team needs to include someone who is a current real-world practitioner in the field being researched.

It needs to be more practical and less theoretical. Moreover, stop creating new catch cries, keep the language simple.

Sorry, but academic research is often too far removed from reality to be of value to anyone.

The qualitative analyses and direct quotes provide a window to the mindset of accounting practitioners. Such analysis is useful to understanding issues and problems from the perspective of practitioners, and further highlights the research practice gap between academia and the accounting profession.

\section{Discussion}

\subsection{Summary of Results}

The study found that accountants do read professional material and the frequency rates do compare favourably with the other two professions. The major difference occurs between the rate of reading of professional material and that of reading academic material. If we compare the frequency reading rate of monthly or more (which includes daily, weekly and monthly), the reading rates of non-academic material are high for all three professions, accounting $(95.4 \%)$, engineering $(97.1 \%)$ and medicine $(100 \%)$. When the figures are compared to reading academic material, the accounting rate declines dramatically to $21.3 \%$, with engineering being $56 \%$ and medicine $91.5 \%$. Another way to view these figures is that nearly 80 percent of accountants rarely or never read academic material. This compares with less than 45 percent for engineers and less than 10 percent for medical practitioners. Further evidence supporting the lack of interest in academic material by accountants is the fact that a majority (51.3\%) never read academic material. This compares to $11.1 \%$ for engineering and $3.4 \%$ for medicine. The descriptive findings paint a picture in which the level of interaction with academic material for the accounting profession is very low, significantly lower when compared to the engineering profession and dramatically lower compared to medicine.

When the data were analyzed deeper, the null hypothesis predicting that accountants did not utilize academic research journals could not be rejected. This is an understandable outcome, as only $4.1 \%$ of accountants indicated they read academic material on a daily or weekly basis. The more telling outcomes from this analysis is the fact that the null hypotheses for both engineering and medicine were rejected, therefore providing us with the scientific evidence that both professions regularly read research published in academic journals. In achieving these significant outcomes, it should be remembered that participants could select from nine different information sources. In other words, from these nine sources of information, engineers and medical practitioners found research journals to be a highly significant source of information, whereas accountants did not.

While the first research question analyzed data individually for each profession, the second research question combined the data into one data set and analyzed for significant differences. The findings found that there were significant differences between accounting and engineering, and accounting and medicine, for each of the three dependent variables tested. These outcomes provide evidence that there are significant differences between accounting and the other two professions with respect to the level of reading and use of academic material, and the future role of academia.

In an attempt to gauge practitioners' desire to read the 'best' articles (most cited) produced by academia, again the findings were disappointing, with only $25 \%$ of accountants showing interest in 
what the academic world would class as their most influential accounting research. This outcome provides some indication of the level of disconnect between practice and academia. If one in two practitioners cannot understand the title of accounting research and only one in four are interested in reading these popular research articles, then one could conclude that the connection between practice and academia is problematic at best. There are likely views from within academia and business schools that these articles were not written for practitioners, but if this is the case, then it brings into question what the research is being produced for, and why governments and universities are spending scarce research funds on accounting research.

With respect to the qualitative analyses, many accountants expressed the need for academics to build stronger research links with ASIC and the professional accounting bodies. They highlighted the difficulties associated with complying with the Australian Securities and Investments Commission (ASIC) 'one size fits all' policy, which covers accounting/auditing rules for all companies from micro/small through to large/multinationals. Linked to this issue was the need for the Accounting Standards to be simplified. Many argued that research should be relevant to accountants, while others stated that academics should better explain how theory relates/improves accounting practice. It was clear from the qualitative data that many practitioners feel frustrated with both ASIC and academia. It is also clear that many of the points being made by practitioners are logical, relevant and important. The results of this paper indicate that academia is not only failing practitioners but the wider profession in general, including ASIC and professional accounting bodies.

\subsection{Practical Implications}

Near the end of the literature review, two issues are highlighted (Sections 3.5 and 3.6). These two sections emphasize the political and social changes currently taking place with regards to the funding of academic research, along with ensuring that public research funds are linked to achieving practical outcomes and to the needs of society. In other words, as governments and stakeholders discuss how best to efficiently allocate scarce public funding to universities, a key point of concern for business schools is 'how relevant is their research and what impact is it having on society?'. To help address these concerns, a number of countries have or are introducing performance-based research funding systems (PRFSs).

As the findings from this study have found, the relevance level of research produced by accounting academics is very low, and with such low relevance, comes the critical issue of having little or no impact on the profession, and ultimately society. Clearly, this study has highlighted major performance deficiency with respect to the usefulness of academic accounting research to practice and the profession. If future academic research funding for the profession was based on the perception of accounting practitioners, then one would question why there is a need for any on-going public funding. While this may seem like a harsh conclusion, it can be argued that the current disconnect of accounting researchers from the profession is a problem solely created by accounting academics, business schools, and the universities themselves. Clearly, the focus on publishing in top-tier journals and improving the university's global ranking has encouraged the disengagement of academia from the practitioners and profession it is funded to serve.

Another important point about this research is the discipline area chosen for this study, being accounting. Within business schools, accounting is maybe the only discipline which can claim similar status to other applied professions, such as medicine, education, teaching, engineering and law. This 'status' comes from the fact that these professions require those who practice within the profession to obtain membership from an overarching organization/body, which controls the granting and renewal of a license to practice. It is therefore logical to reason that being a 'status profession' within society is likely to offer those overseeing the profession a stronger position to argue for research funding than those disciplines and professions that do not have the attached status. In effect, this issue of 'status' acts as a double-edged sword, obligating the research community to produce outcomes which are aligned and focused to the benefit and future advancement of the profession, and therefore society. 
Finally, while the issue of irrelevance is unlikely to have a major short-term effect, the medium to longer-term implications for business schools research is much more uncertain. In a discussion about the research/practice gap and the need for more applied research with a focus on solving real-world problems, Professor Bertil Andersson, the president of one of the world's leading universities, Singapore's Nanyang Technological University, issued the following warning: 'The stick is that if we as an academic system don't deliver, the money will disappear, not overnight but slowly' [116] (p. 9).

\subsection{Study Limitations}

One area that could attract criticism about this study is the fact it is was conducted on one western country, Australia. While a 'value for money' test for business schools research in Australia is likely to be negative, it does not diminish the fact that the research was a single country study, therefore limiting the generalization of the studies' outcomes. Another issue of generalization for this paper is the fact that criticism of accounting research is also applied to business schools in general. An understandable argument would be that a study of accounting research cannot be used to generalize for other businessand management-related disciplines. While any such criticism would be warranted, the authors of this study, when undertaking the review of accounting literature also reviewed a large quantity of articles discussing other research fields in business schools. While accounting is a leading source for criticism, the authors of this study found that other disciplines within business school were also receiving negative critique for its lack of usefulness and impact on the real-world of practice and society. Further limitations of the study are the 'broadness' associated with researching academic disciplines/professions as single identities, which tends to dilute the unique individual characteristics of the specialized fields within a discipline/profession. In effect, these two limitations create an inverse of generalizations. On one hand, the term 'accounting' is used to represent a unique field within business schools, while on the other hand, 'accounting' is used to represent all disciplines within business schools. Finally, while the study aimed to obtain a balanced number of participants from the various fields of accounting, it should be noted that this study is biased towards tax accountants, working in local firms with 20 or less employees.

\section{Conclusions}

The motivation for this paper is to empirically explore the gap between research produce by accounting academics and its usefulness to the accounting profession. The real-world relevance of research being published by accounting academics is receiving an increasing level of criticism (mainly anecdotal) by many within the profession, which includes senior and high-profile academics, editors and publishers, governments and professional accounting bodies, and accounting regulatory institutions. Many have argued that the research practice gap is wider in accounting than other academic disciplines, and the findings of this study would support this hypothesis. Using other applied sciences like medicine and engineering as comparisons, this study empirically found that academic accounting research provides very little real-world relevance, practical usefulness and social impact. While the aim of the paper is to draw attention and bring into focus again this problem, the underlying issue remains, 'How do we address it?' Over the last few decades, a number of articles discussing the issue have offered suggestions for future considerations, but the findings of this paper suggest that little has changed.

It is at this point that the authors of this paper break with common tradition, where normally suggestions for future research are provided. Instead, 10 thought-provoking propositions are listed in the hope of not only provoking responses from the academic community, but to also stimulate debate from a wider range of stakeholders, such as policy makers, funding organizations, professional bodies and the accounting profession at large. 
1. If the world asked medical and engineering researchers to highlight research, which had advanced mankind over the past 50 years, a likely outcome would be a large list of achievements. If the world asked accounting researchers the same question, how many achievements would be listed?

2. Medical and engineering research is routinely used in the education of their undergraduate and postgraduate students. How many of the 1000s of accounting articles published each year are useful in the education of accounting students?

3. Key stakeholders such as the US and international regulatory and standard setting authorities have for several decades pleaded with academia to assist them with research, even offering data and funding, but all cries for help have been ignored by accounting researchers. How and why has this situation been allowed to occur over such a long period of time?

4. Accounting editors and publishers, such as Rhoda Brown, a senior accounting academic, and Rebecca Marsh, a major Publishing Director of accounting material, argue that academic accounting researchers have abandon the profession they seek to research and write about. What is it indicating if editors and publishers of accounting are openly critical of academia?

5. It is argued that the elite academic accounting community spend their time engaging in useless paradigm wars, building 'boy's clubs' for so-called elite American accounting journals, and producing thousands of research articles which have no value or relevance to the accounting profession, accounting practitioners, and the world as a whole. Is this a true assessment of academia, especially at the elite end of accounting research?

6. If a minister from any government, whose ministerial portfolio was linked to either finance, higher education, or science, research and innovation, decided to stop funding academic accounting research, would such a decision be justified? The reaction from researchers and accounting faculties of such a decision would likely be negative, but would that reaction be justified?

7. In 2008, the world witnessed the Global Financial Crisis (GFC), a meltdown of the world's financial, accounting, and auditing systems. Why did thousands of highly paid accounting professors around the globe not have a single clue on what was going on? More pointedly, how could the American academic accounting elites, who were at the epicenter of the crisis, be totally oblivious to the unfolding massive human and social disaster? How is it, after more than a decade on from the crisis, there are those who argue that nothing has changed in the US, and an identical event could occur all over again?

8. It is clear to many that research being produce in accounting faculties is predominately published to enhance university and academic status, with very little thought being given to the usefulness and relevance of the research to the profession, practitioners and society. In an applied field like accounting, is this a sustainable model?

9. This paper is filled with criticism from those who are on the inside of the accounting profession. It is likely that no other academic discipline generates the level of criticism from within. Why does accounting attracts so much criticism from within its own ranks, and why are so many high-profile insiders critical of the current state of academic accounting research?

10. Finally, after decades of debate about the usefulness of academic accounting research, should public money continue to be used to fund research in accounting faculties?

Author Contributions: Both authors have contributed equally to the development and writing of all aspects of this article. All authors have read and agreed to the published version of the manuscript.

Funding: This research received no external funding.

Conflicts of Interest: The authors declare no conflict of interest. 


\section{References}

1. Abdel-Khalik, A.R.; Keller, T.F. The Impact of Accounting Research on Practice and Disclosure; Duke University Press: Durham, NC, USA, 1978.

2. Inanga, E.L.; Schneider, W.B. The Failure of Accounting Research to Improve Accounting Practice: A Problem of Theory and Lack of Communication. Crit. Perspect. Account. 2005, 16, 227-248. [CrossRef]

3. Williams, P.F.; Jenkins, J.G.; Ingraham, L. The Winnowing Away of Behavioral Accounting Research in the US: The Process for Anointing Academic Elites. Account. Organ. Soc. 2006, 31, 783-818. [CrossRef]

4. Barth, M.E. Financial Accounting Research, Practice, and Financial Accountability. Abacus 2015, 51, 499-510. [CrossRef]

5. Ewert, R.; Wagenhofer, A. Using Academic Research for the Post-Implementation Review of Accounting Standards: A Note. Abacus 2012, 48, 278-291. [CrossRef]

6. Fraser, K.; Deng, X.; Bruno, F.; Rashid, T.A. Should Academic Research Be Relevant and Useful to Practitioners? The Contrasting Difference between Three Applied Disciplines. Stud. High. Educ. 2020, 45, 129-144. [CrossRef]

7. Malmi, T.; Granlund, M. In Search of Management Accounting Theory. Eur. Account. Rev. 2009, 18, 597-620. [CrossRef]

8. Palea, V. Whither Accounting Research? A European View. Crit. Perspect. Account. 2017, 42, 59-73. [CrossRef]

9. Tucker, B.; Lowe, A. Practitioners Are from Mars; Academics Are from Venus? Account. Audit. Account. J. 2014, 27, 394-425. [CrossRef]

10. Ghoshal, S. Bad Management Theories Are Destroying Good Management Practices. Acad. Manag. Learn. Educ. 2005, 4, 75-91. [CrossRef]

11. Markides, C. In Search of Ambidextrous Professors. Acad. Manag. J. 2007, 50, 762-768. [CrossRef]

12. Brown, R. Revisiting the Expectations Gaps after 15 Years. J. Appl. Account. Res. 2009, 10, 92-95. [CrossRef]

13. Brooks, C.; Fenton, E.; Schopohl, L.; Walker, J. Why Does Research in Finance Have so Little Impact? Crit. Perspect. Account. 2019, 58, 24-52. [CrossRef]

14. Geuna, A.; Martin, B.R. University Research Evaluation and Funding: An International Comparison. Minerva 2003, 41, 277-304. [CrossRef]

15. Hicks, D. Performance-Based University Research Funding Systems. Res. Policy 2012, 41, 251-261. [CrossRef]

16. Lewis, J.M. Research Productivity and Research System Attitudes. Public Money Manag. 2014, 34, 417-424. [CrossRef]

17. Muscio, A.; Quaglione, D.; Vallanti, G. Does Government Funding Complement or Substitute Private Research Funding to Universities? Res. Policy 2013, 42, 63-75. [CrossRef]

18. Fraser, K.; Tseng, B.; Deng, X. The Ongoing Education of Engineering Practitioners: How Do They Perceive the Usefulness of Academic Research? Eur. J. Eng. Educ. 2018, 43, 860-878. [CrossRef]

19. Baldvinsdottir, G.; Mitchell, F.; Norreklit, H. Issues in the Relationship between Theory and Practice in Management Accounting. Manag. Account. Res. 2010, 21, 79-82. [CrossRef]

20. Lindsay, R.M. We Must Overcome the Controversial Relationship between Management Accounting Research and Practice. Pac. Account. Rev. 2012, 24, 357-375. [CrossRef]

21. Mattessich, R. Critique of Accounting: Examination of the Foundations and Normative Structure of an Applied Discipline; Quorum Books: Westport, CT, USA, 1995.

22. McCarthy, W.E. Accounting Craftspeople versus Accounting Seers: Exploring the Relevance and Innovation Gaps in Academic Accounting Research. Account. Horiz. 2012, 26, 833-843. [CrossRef]

23. Merchant, K.A. Making Management Accounting Research More Useful. Pac. Account. Rev. 2012, 24, 334-356. [CrossRef]

24. Fraser, K.E. Defeating the 'Paradigm Wars' in Accounting: A Mixed Methods Approach Is Needed in the Education of PhD Scholars. Int. J. Mult. Res. Approaches 2014, 8, 49-62. [CrossRef]

25. Krauss, S. Research Paradigms and Meaning Making: A Primer. Qual. Rep. 2005, 10, 758-770.

26. Baker, C.; Bettner, M. Interpretive and Critical Research in Accounting: A Commentary on Its Absence from Mainstream Accounting Research. Crit. Perspect. Account. 1997, 8, 293-310. [CrossRef]

27. Fendt, J.; Kaminska-Labbe, R.; Sachs, W. Producing and Socializing Relevant Maangement Knowledge: Re-Turn to Pragmatism. Eur. Bus. Rev. 2008, 20, 471-491. [CrossRef] 
28. Kelemen, M.; Rumens, N. An Introduction to Critical Management Research; Sage: London, UK, 2008.

29. Wicks, A.C.; Freeman, R.E. Organization Studies and the New Pragmatism: Positivism, Anti-Positivism, and the Search for Ethics. Organ. Sci. 1998, 9, 123-140. [CrossRef]

30. May, C.; Finch, T. Implementation, Embedding, and Integration: An Outline of Normalization Process Theory. Sociology 2009, 43, 535-554. [CrossRef]

31. Humphrey, C.; Gendron, Y. What Is Going on? The Sustainability of Accounting Academia. Crit. Perspect. Account. 2015, 26, 47-66. [CrossRef]

32. Blackwell, A. Taking Account of Research Outcomes. Campus Rev. 2011, 7, 3.

33. Laughlin, R. Accounting Research, Policy and Practice: Worlds Together or Worlds Apart? In Bridging the Gap Between Academic Accounting Research and Professional Practice; ICA: Sydney, Australia, 2011.

34. Kaplan, R.S. Accounting Scholarship That Advances Professional Knowledge and Practice. Account. Rev. 2011, 86, 367-383. [CrossRef]

35. Hopwood, A.G. Whither Accounting Research? Account. Rev. 2007, 82, 1365-1374. [CrossRef]

36. Hopwood, A.G. The Economic Crisis and Accounting: Implications for the Research Community. Account. Organ. Soc. 2009, 34, 797-802. [CrossRef]

37. Scapens, R.W. Seeking the Relevance of Interpretive Research: A Contribution to the Polyphonic Debate. Crit. Perspect. Account. 2008, 19, 915-919. [CrossRef]

38. Scapens, R.W. How Important Is Practice-Relevant Management Accounting Research? Qual. Res. Account. Manag. 2012, 9. [CrossRef]

39. Granof, M.; Zeff, S.A. Research on Accounting Should Learn from the Past. Chron. High. Educ. 2008, 21, A34.

40. Jeanjean, T.; Ramirez, C. Back to the Origins of Positive Theories: A Contribution to an Analysis of Paradigm Changes in Accounting Research. Account. Eur. 2009, 6, 107-126. [CrossRef]

41. Walton, P. European Accounting Research-A Comment. Account. Eur. 2008, 5, 1-13. [CrossRef]

42. Arnold, P.J. Global Financial Crisis: The Challenge to Accounting Research. Account. Organ. Soc. 2009, 34, 803-809. [CrossRef]

43. McDonald, M.; Pitsis, T.; Wearing, M. Let Academics Work in the Real World. High. Educ. Aust. 2011, 15, 29.

44. van Helden, G.J.; Northcott, D. Examining the Practical Relevance of Public Sector Management Accounting Research. Financ. Account. Manag. 2010, 26, 213-240. [CrossRef]

45. Marsh, R. Measuring the Impact of Research. J. Appl. Account. Res. 2010, 11, 78-79.

46. Unerman, J.; O'Dwyer, B. The Relevance and Utility of Leading Accounting Research. In Research Report 120; ACCA: London, UK, 2010; ISBN 978-1-85908-467-0.

47. Tucker, B.; Schaltegger, S. Comparing the Research-Practice Gap in Management Accounting. Account. Audit. Account. J. 2016, 29, 362-400. [CrossRef]

48. Schiller, B. Academia Strives for Relevance. Financ. Times 2011, 25, 13.

49. Trounson, A.; Hare, J. Call to End 'Elitist Attitude'. High. Educ. Aust. 2012, 25, 31.

50. Tapp, A. Why Practitioners Don't Read Our Articles and What We Should Do about It. Mark. Rev. 2005, 5, 3-12. [CrossRef]

51. Turner, D. Great Expectations: The Social Sciences in Britain. Reg. Mag. 2003, 248, 4-5.

52. Singleton-Green, B. Public Policy and Accounting Research: What Is to Be Done? Account. Eur. 2015, 12, 171-186. [CrossRef]

53. Singleton-Green, B. The Communication Gap: Why Doesn't Accounting Research Make a Greater Contribution to Debates on Accounting Policy. Account. Eur. 2010, 7, 129-145. [CrossRef]

54. OECD. Connecting to Knowledge. In OECD Science, Technology and Industry Scoreboard 2013; OECD Publishing: Paris, France, 2013.

55. Research Australia. Boosting the Commercial Returns from Research; Research Australia: Sydney, Australia, 2014.

56. Beresford, D. A Request for More Research to Support Financial Accounting Standard-Setting AAA-Accounting. Behav. Res. Account. 1994, 6, 190-203.

57. Leisenring, J.J.; Johnson, L.T. Accounting Research: On the Relevance of Research to Practice. Account. Horiz. 1994, 8, 74-79.

58. Fulbier, R.U.; Hitz, J.M.; Sellhorn, T. Relevance of Academic Research and Researchers' Role in the IASB's Financial Reporting Standard Setting. Abacus 2009, 45, 455-492. [CrossRef]

59. Demski, J.S.; Dopuch, N.; Lev, B.; Ronen, J.; Searfoss, G.; Sunder, S. A Statement on the State of Academic Accounting. Statement Res. Dir. Am. Account. Assoc. 1991, 22. unpublished letter. 
60. Aguinis, H.; Cascio, W.F. Narrowing the Science-Practice Divide: A Call to Action. Ind. Psychol. 2008, 46, 27.

61. Bennis, W.G.; O’Toole, J. How Business Schools Lost Their Way. Harv. Bus. Rev. 2005, 83, 96-104.

62. Dess, G.G.; Markoczy, L. Rather than Searching for the Silver Bullet, Use Rubber Bullets: A View on the Research-Practice Gap. J. Supply Chain Manag. 2008, 44, 57-62. [CrossRef]

63. Dyckman, T.R.; Zeff, S.A. Accounting Research: Past, Present, and Future. Abacus 2015, 51, 511-524. [CrossRef]

64. Wilkinson, B.R.; Durden, C.H. Inducing Structural Change in Academic Accounting Research. Crit. Perspect. Account. 2015, 26, 23-36. [CrossRef]

65. McNatt, D.B.; Glassman, M.; Glassman, A. The Great Academic-Practitioner Divide: A Tale of Two Paradigms. In ScholarWorks; Boise State University: Boise, ID, USA, 2010; Volume 15.

66. Lukka, K. The Roles and Effects of Paradigms in Accounting Research. Manag. Account. Res. 2010, 21, 110-115. [CrossRef]

67. Malmi, T. Reflections on Paradigms in Action in Accounting Research. Manag. Account. Res. 2010, 21, 121-123. [CrossRef]

68. Merchant, K.A. Paradigms in Accounting Research: A View from North America. Manag. Account. Res. 2010, 21, 116-120. [CrossRef]

69. Tucker, B.; Parker, L. In Our Ivory Towers? The Research-Practice Gap in Management Accounting. Account. Bus. Res. 2014, 44, 104-143. [CrossRef]

70. Bromwich, M.; Scapens, R. Management Accounting Research: 25 Years On. Manag. Account. Res. 2016, 31, 1-9. [CrossRef]

71. Tushman, M.; O'Reilly, C. Research and Relevance: Implications of Pasteur's Quadrant for Doctoral Programs and Faculty Development. Acad. Manag. J. 2007, 50, 769-774. [CrossRef]

72. Rutherford, B.A. Accounting Research and Accounting Policy: What Kind of Gap? Account. Eur. 2011, 8, 141-154. [CrossRef]

73. Pettigrew, T.J. Management Research after Modernism. Br. J. Manag. 2001, 12, S61-S70. [CrossRef]

74. Mohrman, S.A.; Lawler, E.E. Useful Research: Advancing Theory and Practice. In Useful Research: Advancing Theory and Practice; Berrett-Koehler: San Francisco, CA, USA, 2011; pp. 9-36.

75. Fraser, K.; Hvolby, H.-H.; Tseng, B. Maintenance Management Models: A Study of the Published Literature to Identify Empirical Evidence. A Greater Practical Focus Is Needed. Int. J. Qual. Reliab. Manag. 2015, 32, 635-664. [CrossRef]

76. Diamond, M. Accounting Education, Research and Practice: After Enron, Where Do We Go? Eur. Account. Rev. 2005, 14, 353-362. [CrossRef]

77. Karan, R. Implications for Third Party Actions against Auditors of Recently Failed US Companies and Decision-Usefulness Objective under the New York Rule. Crit. Perspect. Account. 2004, 15, 927-941. [CrossRef]

78. Bayou, M.E.; Reinstein, A.; Williams, P.F. To Tell the Truth: A Discussion of Issues Concerning Truth and Ethics in Accounting. Account. Organ. Soc. 2011, 36, 109-124. [CrossRef]

79. Coleman, L. Why Finance Theory Fails to Survive Contact with the Real World: A Fund Manage Perspective. Crit. Perspect. Account. 2014, 25, 226-236. [CrossRef]

80. Lee, T. Shaping the US Academic Accounting Research Profession: The American Accounting Association and the Social Construction of a Professional Elite. Crit. Perspect. Account. 1995, 6, 241-261. [CrossRef]

81. Jones, M.J.; Brinn, T.; Pendlebury, M. Judging the Quality of Research in Business Schools: A Comment from Accounting. Omega 1996, 24, 597-602. [CrossRef]

82. Kaplan, R.S.; Norton, D. Using the Balanced Scorecard as a Strategic Management System. Harv. Bus. Rev. 1996, 74, 75-85.

83. Cooper, R.; Kaplan, R.S. Activity-Based Systems: Measuring the Costs of Resource Usage. Account. Horiz. 1992, 6, 1-13.

84. Hope, J.; Fraser, R. Beyond Budgeting: How Managers Can Break Free from the Annual Performance Trap; Harvard Business School Press: Boston, MA, USA, 2003.

85. Simons, R. Levers of Control: How Managers Use Innovative Controls Systems to Drive Strategic Renewal; Harvard Business School Press: Boston, MA, USA, 1995.

86. Scott, W.R. Financial Accounting Theory; Peason: Toronto, ON, Canada, 2015.

87. Hopwood, A.G. An Accounting System and Managerial Behaviour; Saxon: London, UK, 1973. 
88. Merchant, K.A. Rewarding Results: Motivating Profit Center Managers; Harvard Business School Press: Boston, MA, USA, 1989.

89. Trombetta, M.; Wagenhofer, A.; Wysocki, P. The Usefulness of Academic Research in Understanding the Effects of Accounting Standards. Account. Eur. 2012, 9, 127-146. [CrossRef]

90. Flynn, B.B. Having It All: Rigor versus Relevance in Supply Chain Management Research. J. Supply Chain Manag. 2008, 44, 63-67. [CrossRef]

91. Hodgkinson, G.P.; Rousseau, D.M. Bridging the Rigour-Relevance Gap in Management Research: It's Already Happening! J. Manag. Stud. 2009, 46, 534-546. [CrossRef]

92. Kieser, A.; Leiner, L. Why the Rigour-Relevance Gap in Management Research Is Unbridgeable. J. Manag. Stud. 2009, 46, 516-533. [CrossRef]

93. Mentzer, J.T. Rigor versus Relevance: Why Would We Choose Only One? J. Supply Chain Manag. 2008, 44, 72-77. [CrossRef]

94. Vermeulen, F. On Rigor and Relevance: Fostering Dialectic Progress in Management Research. Acad. Manag. J. 2005, 48, 978-982. [CrossRef]

95. Fraser, K.E. Is Indonesia Producing Enough Business Graduates to Assist Its Development Aspirations. Ind. High. Educ. 2013, 27, 85-88. [CrossRef]

96. McKinnon, A.C. Starry-Eyed: Journal Rankings and the Future of Logistics Research. Int. J. Phys. Distrib. Logist. Manag. 2013, 43, 6-17. [CrossRef]

97. Harzing, A.-W. Australian Research Output in Economics and Business: High Volume, Low Impact? Aust. J. Manag. 2005, 30, 183-200. [CrossRef]

98. Jensen, P.; Webster, E. Let's spend more wisely on research in Australia. Conversation 2014.

99. Weighley, S.; Hess, A.E.M. Universities Getting the Most Government Money. 24/7 Wall St. 2013. Available online: http://247wallst.com/special-report/2013/04/25/universities-getting-the-most-government-money/ (accessed on 7 November 2014).

100. OECD. Performance-Based Funding for Public Research in Tertiary Education Institutions. In Workshop Proceedings; OECD Publishing: Paris, France, 2010.

101. Sanz-Menendez, L.; Cruz-Castro, L. Coping with Environmental Pressures: Public Research Organizations Responses to Funding Crisis. Span. Policy Res. Innov. Technol. Train. Educ. 2002, 19, 2-19. [CrossRef]

102. Kealey, T. The Economic Laws of Scientific Research; Macmillan Press: London, UK, 1996.

103. Salter, A.J.; Martin, B.R. The Economic Benefits of Publicly Funded Basic Research: A Critical Review. Res. Policy 2001, 30, 509-532. [CrossRef]

104. Pavitt, K. Why European Union Funding of Academic Research Should Be Increased: A Radical Proposal. Sci. Public Policy 2000, 27, 455-460. [CrossRef]

105. Narin, F.; Hamilton, K.S.; Olivastro, D. The Increasing Linkage between U.S. Technology and Public Science. Res. Policy 1997, 26, 317-330. [CrossRef]

106. Hawawini, G. The Future of Business Schools. J. Manag. Dev. 2005, 24, 770-782. [CrossRef]

107. Koelman, J.; Venniker, R. Public Funding of Academic Research: The Research Assessment Exercise of the UK. In Higher Education Reforms: Getting the Incentives Righ; UT Publications: Dutch, The Netherlands, 2001.

108. Trounson, A. Australian Technology Network Looks to Rank Uni Engagement with Business. High. Educ. Aust. 2014, 30, 18.

109. European Commission. Assessing Europe's University-Based Research. EUR 24187 EN. In Science in Society 2008; European Commission: Brussels, Belgium, 2010.

110. Palmer, D. Taking Stock of the Criteria We Use to Evaluate One Another's Work: ASQ 50 Years Out. Adm. Sci. Q. 2006, 51, 535-559. [CrossRef]

111. Boynton, P.M.; Greenhalgh, T. Selecting, Designing, and Developing Your Questionnaire. Br. Med. J. 2004, 328, 1312-1315. [CrossRef]

112. Hinkin, T.R. A brief tutorial on the development of measures for use in survey questionnaires. Organ. Res. Methods 1998, 1, 104-121. [CrossRef]

113. Tuan, H.-L.; Chin, C.-C.; Shieh, S.-H. The Development of a Questionnaire to Measure Students' Motivation towards Science Learning. Int. J. Sci. Educ. 2005, 27, 639-654. [CrossRef]

114. Neuman, W.L. Social Research Methods. Qualitative and Quantitative Approaches; Allyn, B., Ed.; Sage: Boston, MA, USA, 2000. 
115. Pallant, J. SPSS Survival Manual; Open University Press: New York, NY, USA, 2005.

116. Trounson, A. Universities 'Need to Work on Real-World Issues'. High. Educ. Aust. 2015, $27,9$.

Publisher's Note: MDPI stays neutral with regard to jurisdictional claims in published maps and institutional affiliations.

(C) 2020 by the authors. Licensee MDPI, Basel, Switzerland. This article is an open access article distributed under the terms and conditions of the Creative Commons Attribution (CC BY) license (http://creativecommons.org/licenses/by/4.0/). 